\title{
Collaborative governance: assessing the problem of weak cross-sectoral collaborations for the governance of Addis Ababa Rivers
}

\author{
Wassihun Gebregiziaber Woldesenbet ${ }^{1}$
}

Received: 20 February 2018 / Accepted: 28 June 2018 / Published online: 6 July 2018

(c) The Author(s) 2018

\begin{abstract}
Even though collaborative governance has become an important model to address river problems, the practice of collaboration among different sectors to govern river problems is weak in Addis Ababa city. Therefore, this study was intended to investigate the problem of weak cross-sectoral collaboration for the governance of river problems in Addis Ababa City. Employing qualitative research approach, the study relied on both primary and secondary data sources. Accordingly, interview and observation were conducted to gather relevant data. Secondary data were collected from different quarterly reports, river assessments and researches. The study found out that cross-sectoral collaboration is characterized by the lack of involvement of various non-governmental sectors, the problem of legitimacy, and the representation of sectors by individuals who have no expertise or experience on river issues. On the other hand, the challenges are the exclusion of river from the agendas of each sector, lack of commitment of authorities to share information and resources, and the absence of sectors in the implementation of river plans in different river sites in terms of giving trainings, supervising, and evaluating river sites. Establishing committee at all levels, including river in the annual plans of each sector, and appointing river experts in different sectors are identified as important mechanisms of dealing with collaboration problems. These problems of weak cross-sectoral collaborative governance of rivers had resulted in the deteriorating quality of rivers, environmental hazards to the vegetation of agricultural crops, and health and related impacts on biotic elements of the ecosystem.
\end{abstract}

Keywords Collaborative governance $\cdot$ Cross-sectoral collaboration $\cdot$ River governance

\section{Introduction}

The problem of rivers particularly in the context of governance and management is one of the preeminent problems in the contemporary era (Olsson and Head 2015). The causes of urban river resource crisis basically emerge from different factors. According to Chan (2009), the current river crisis has been mainly caused not just by a lack of technology but rather by a failure in the governance structures. Particularly, urban river problems arise, in addition to pollution, illegal dumping of wastes, scarcity, and others, mainly from another context: weak cross-sectoral collaboration in the governance of rivers. Though urban rivers are providing various life-supporting services, urbanization, pollution, and uncontrolled

Wassihun Gebregiziaber Woldesenbet

zemahbereyordanos@gmail.com

1 Regional and Local Development Studies, Department of Civics and Ethical Studies, College of Social Sciences and Humanities, Wolkite University, Wolkite, Ethiopia waste dumping have impacted on rivers, and thus a collaborative framework that pools resources and legitimacy from different sectors has to be practiced (Olsson and Head 2015).

In order to address this global concern, new theoretical frameworks are emerging. Collaborative governance has become a mechanism to address river problems. Addressing river problems through the involvement of various sectors has gained recognition in different countries (Salman and Daniel 2006; Newig and Fristch 2009). Collaborative river governance is very important to effectively deal with urban river problems. Although there is no a precise definition, the term collaborative governance is increasingly used to refer to policy approaches that encompass some or all of the following characteristics: collaboration, participation, integration, learning, adaptation, and region-based decision making (Cameron 2017).

Summarizing seven kinds of literature on urban river governance, Olsson and Head (2015) explained that the problem of rivers in cities needs to take environmental, legal, and social concerns into account; and in addressing this river 
problem, collaborative governance approaches are needed. Though cross-sectoral collaborative governance has emerged as a mechanism to deal with river problems, little is known about how such processes of collaboration in decision making, mutual learning, and implementation are going on (Holt et al. 2012). Thus, cross-sectoral collaboration in the governance of urban river resources has been emphasized in different kinds of literature as an important subject to be deeply investigated (Franzen et al. 2014). Thus, there is literature gap in this regard which requires more scientific exploration.

In the same way, the problem of weak cross-sectoral collaboration for the governance of rivers is one of the concerns in Addis Ababa City. Explaining how rivers in Addis Ababa City are deteriorating from a different context, a river assessment that was conducted by Meklit et al. (2016) emphasizes that the collaboration of different sectors for the governance of rivers is weak. Though different sectors are responsible for the problem of rivers, there is weak collaboration among different sectors to govern such river problems. Cross-sectoral collaboration for the governance of rivers in Addis Ababa is weak, and it has to be well investigated to understand the depth of the problem (Berisso et al. 2016). Therefore, the problem of weak cross-sectoral collaboration for the governance of rivers is one of the central issues in Addis Ababa City and it has to be investigated.

Addis Ababa Rivers have been the subject of several types of research and project works from different fields. Most of them, which are from the natural science fields, dealt with the technical, chemical, and engineering aspect of Addis Ababa Rivers. Using physiochemical parameters, Solomon et al. (2011) conducted an assessment of human impacts on the Akaki River and concluded that factors affecting Akaki River are different: industrial, residential, and hospital wastes. Another research by Agajie (2007) on the suitability assessment of Akaki River revealed that the Akaki River is at a high risk of bacteriological pollution, and thus the river is not usable as such. Another research by Chali (2015), using engineering software, on Gefersa water supply tells a similar story. Tamiru (2003) also noted that Rivers in Addis Ababa are deteriorating. Many of them found out that Addis Ababa Rivers are facing serious deterioration due to many factors. However, though many research works were conducted to investigate the river crisis from different dimensions, none of them dealt with the governance problems and cross-sectoral collaboration aspects of rivers. They suggested that water and environmental agencies should work for the protection and development of the rivers. Though there have been many workshops and governmental meetings in which the necessity of cross-sectoral collaboration is understood to be of significant, there is no any research work that investigated the nature of collaborations among sectors in governing rivers in Addis Ababa City.
Therefore, it is against this specific gap that this study is intended to be conducted to make an assessment and fill the gap in knowledge with regard to weak cross-sectoral collaboration for the governance of Addis Ababa Rivers. The problem of weak cross-sectoral collaboration to govern rivers, the constraining factors of collaboration, and the appropriate mechanisms of strengthening collaboration for the governance of Addis Ababa Rivers are worth researching. In light of this, critical investigation of weak collaboration among sectors largely complements to properly address river problems of Addis Ababa city.

\section{Research objective}

- To identify the challenges of cross-sectoral collaboration in collectively governing Addis Ababa rivers.

\section{Research question}

- What are the major challenges that constrain strong cross-sectoral collaboration among different sectors?

\section{Conceptual framework of the study}

This study was aimed at understanding cross-sectoral collaborative governance of Addis Ababa Rivers. This activity of cross-sectoral collaborative governance of rivers is influenced by the underlying multivariate contexts: the absence of committees that could facilitate the collaboration of different sectors, the commitment and sense of responsibility of authorities, communication and facilitating styles of organizers of collaborative governance activity, the experience and knowledge of representatives of sectors, sectoral principles and objectives, and the exclusion of rivers from the agendas of different sectors. Cross-sectoral collaborations are newly introduced partnerships among sectors that have unique complementary strengths, resources, ideas, principles, authorities, and skills to collectively address common matters. Such collaborative frameworks are systems that bring various sectors' views and enhance their collaboration for interdependence in solving common resources through collective decision making and adoption of common strategies and plans (Warner 2006).

Based on the review of various literatures, the following conceptual framework is developed. According to the conceptual framework, the underlying factors of collaboration, such as low level of commitment and sense of responsibility of responsible authorities and experts, poor facilitative skills of organizers of collaboration, and lack of committees to facilitate cross-sectoral collaborations, lead to the existence of weak cross-sectoral collaborative governance activity. To address such concerns, the establishment of committees, 
the appointment of river experts, and the decentralization of river governance responsibilities across lower levels of sectors are essential (Fig. 1).

\section{Methodology of the study}

\section{Description of the study area}

A critical assessment of secondary sources indicated the presence of 7 major and 6 medium rivers in Addis Ababa although the classifying parameters and the list of the rivers remained unclear (Berisso et al. 2016). These major and medium-sized rivers of the city are fed by nearly 75 small streams and tributaries. According to Berisso et al. (2016), all the rivers in the city fall under two major sub-basins or watersheds, namely (Fig. 2):

a. The Big Akaki River Basin (The Eastern Sub-catchment) and

b. The Small Akaki River Basin (The western Sub-catchment).

Many authors discussed that all the tributaries join the two major rivers (Great Akaki and Small Akaki River) are highly affected by inappropriate human intervention and effects. In general, some of the major rivers of the city are Kebena, Little Akaki, Bantiyketu, Ketchene, Kurtume and

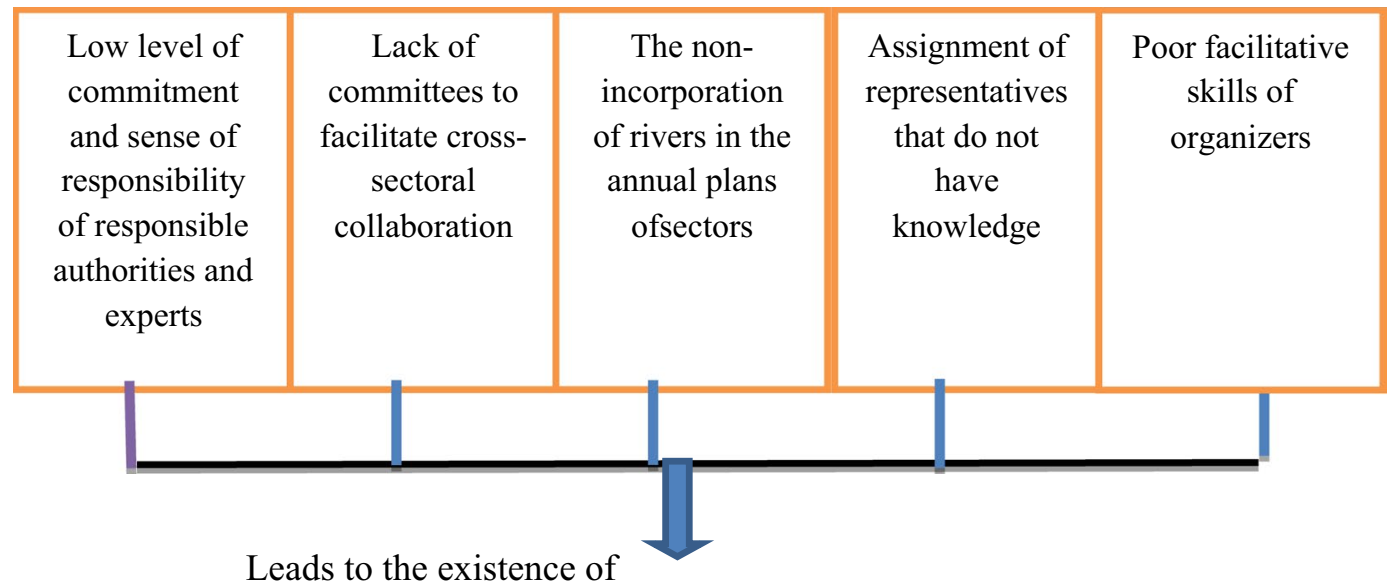

Leads to the existence of

Weak Collaborative governance activity in terms of

- Exchange of information

- Exchange of feedbacks,

- Supervision of river sites

- Evaluation of five site activities

- Mobilization and exchange of resources

- Deliberation and sharing of idea, knowledge

Mechanisms to address the problem of weak cross-sectoral collaborative governance of rivers

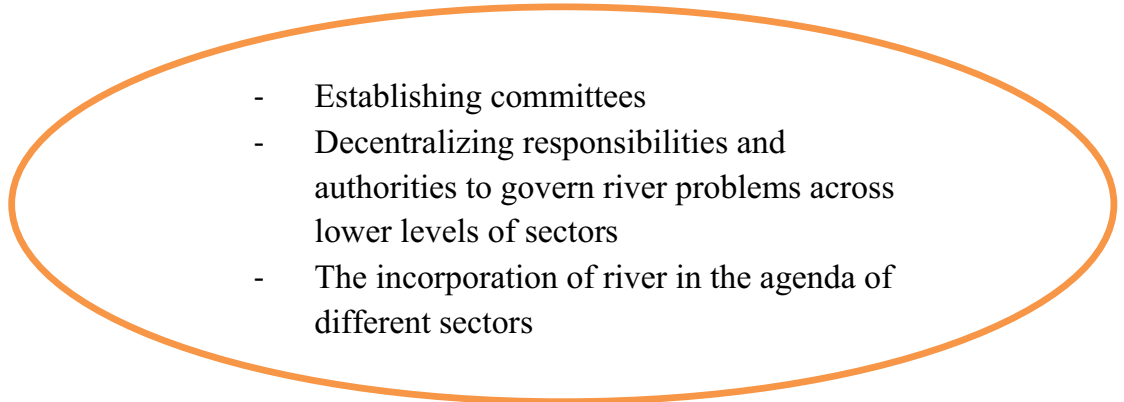

Source: Compiled by the Researcher Based on Review of Literatures

Fig. 1 A conceptual framework that shows how cross-sectoral collaborations in the collective governance of Addis Ababa Rivers are influenced and challenged. Source Compiled by the Researcher Based on Review of Literatures 


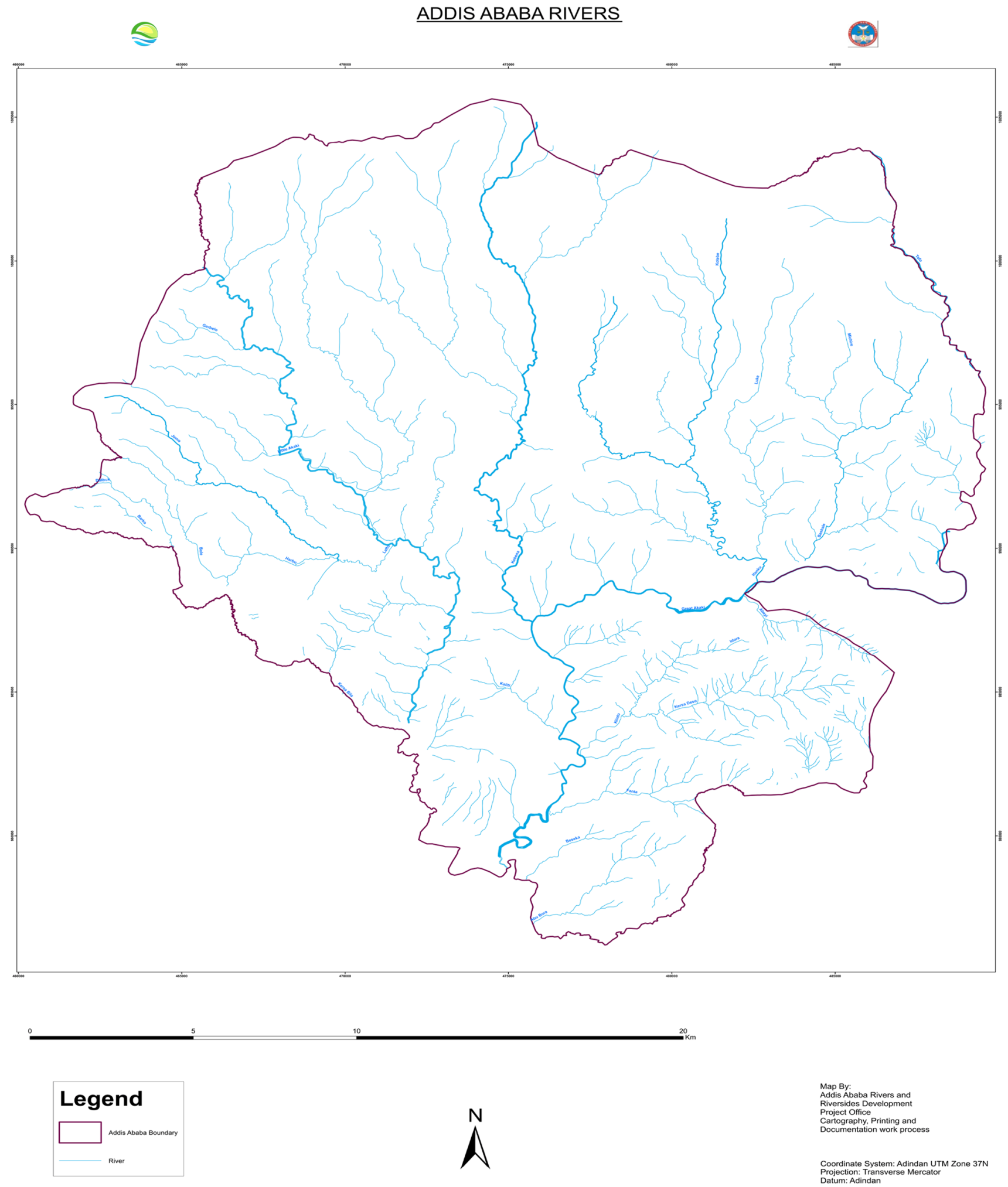

Source: Addis Ababa Rivers, Riversides Climate Change Adaptation Project Office, 2017

A critical assessment of secondary sources indicated the presence of 7 major and 6 medium rivers in Addis Ababa although the classifying parameters and the list of the rivers remained unclear (Berriso et al., 2016). These major and 
4Fig. 2 A geographical map that describes the rivers that are found at Addis Ababa City. Source Addis Ababa Rivers, Riversides Climate Change Adaptation Project Office 2017a, b, c

Big Akaki rivers, while the streams, medium and smaller streams include Ginfile, Buhe, Korsa, Bole, Kotebe, Harbu; Beshale. Buhe, Jemo, and Tafo (Abraham 2012). Addis Ababa Rivers are today facing a great problem in that the level of pollution is very worrisome, and the level of attention given by different sectors and all other responsible stakeholders is very limited (Meklit et al. 2016). Addis Rivers are facing a multitude of problems, including but not limited to an increasing level of pollution, the health and other related consequence of river problems, the lack of appropriate measures that are taken by government and non-governmental organizations, and lack of awareness and responsibility of the community.

Geologically, Addis Ababa Rivers are formed from volcanic rocks and fluvial sediments. These include, among other minerals, "the quaternary scoria, coriaceous and vesicular basalts, Pliocene-quaternary fine grained ignimbrites, tufts and rhyolite, middle Miocene basalts and Oligocene rhyolites". The sub-watershed hydrogeology is formed by productive aquifers, moderately productive aquifers and minor aquifers in the middle parts, and poorly productive aquifers at the top of Entoto and highly productive aquifers at the southern end toward the outlet of the sub-watershed (Ethiopian Environmental Protection Authority 2007).Thermal deep well boreholes in confined aquifers are found in the middle catchments (e.g., at the Filwoha Hotel, National Palace, Hilton and Ghion Hotels), and cold water deep boreholes yield from 3 to $8 \mathrm{l} / \mathrm{s}$ in several locations in middle and lower catchments (Leta et al. 2016).

\section{Research methods and data collection instruments}

Among a variety of qualitative research approaches, case study method has been selected. This is because case study is important to investigate a certain groups of sectors: how they interact with each other in governing rivers, the process of communications, the process of discussions and decision making activities, the process of exchanging feedbacks, making supervisions and evaluations. Thus, all these activities are complex ones that could be understood through case study approach which enables to investigate the depth of social circumstances (Yin 2009). Multi-case study was used in this research as there are multiple cases of cross-sectoral collaborative of different river site projects in the study area, and also increases theoretical replications to other river context through the generation of rich evidences. Multiple case studies are also important tools to understand a certain complex set of events in their own context; wherein cross-organizational processes that involve the participation of different individuals with different characteristics, background, knowledge, and experience influence the process of sectoral collaboration (Bhattcherjee 2012).

Finally, Yin (2009) noted that case studies are important to test theories through the application of several multi-case studies. Thus, the use of three case studies in this research provides lessons and broader evidences to understand collaborative governance from wider perspective across different river sites.

Three case studies were selected, namely River Watch project, Kebena, Gemo, Gelagle, Mariam(Shekla Afer), Mariam (Wengelawit), and Amanuel Condominium Riversides Development Project and 100 K.M. by 100 m River Cleaning, and River Rally Project. The underlying reasons for selecting these case studies were that they are relatively older than the other project activities; they are subjects of emphasis of the river development project office in terms of designing other project activities; fundamental changes in terms of cleaning up and protecting rivers have been achieved in such projects; the collaboration of various sectors has been more intensified in these river sites than in other project sites; and these three cases comprise multiple river protection and development projects in different sites across the rivers.

The sampling technique that was employed in this research to select target sectors and interviewees was nonprobability sampling. Non-probability sampling enables the researcher to identify most relevant targets, to select some group of samples that represent the whole, and to identify most favorable and potential sources of information to the study (Kothari 2004). In this study, the researcher purposively selected those key informants for interview schedules, for they are the most active actors and have the experience, expertise, and sectoral responsibility in collaboratively working on various river project sites. Besides, these selected sectors are also participating in the implementation phase of collaborative governance so that they could provide broad and deep information about the nature and challenges of cross-sectoral collaboration.

Besides, some of the interviewees were purposively selected because of their role as representatives of their sector for cross-sectoral collaborative works; consequently, richer and vast amount of data were collected to deeply understand the problem. In this study, the researcher explored the breadth of the participant sectors in the collaborative governance of rivers, the constraints of cross-sectoral collaborations.

\section{Low level of commitment of responsible authorities of different sectors}

The commitment of authorities is expressed in terms of how willingly they mobilize resources for the collaborative

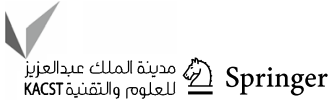


governance activities, initiate mutual discussion forums, engage in the two-way communication systems with other sectors, and timely and quickly share information and resources. In this regard, interviewee from Addis Ababa Rivers, and Riversides Project Office noted the following:

Even though we tried to communicate with different responsible authorities of sectors, we failed to get their quick responses, particularly to get information on the number of schools alongside rivers and their GPS location and map description. Particularly, after discussions have been held, most of the participant sectors were not interested to respond to our continuous requests for resources and feedbacks. We ask them repeatedly, but they are passive in all forms of communications (Interview: 26/04/2017).

On the other hand, interviewee from the Addis Ababa City Education Bureau expressed the following points:

Recently, we have organized and conducted four (4) filed trip activities that were designed to increase the understanding of different Environmental Clubs, experts and students. During such events, only three officials took part though we invited many officials from sub city and Woreda sectors. The rest of them were not committed to participate in such activities. After discussions, the required resources and finances were not mobilized on the expected time (Interview 09 28/04/2017).

Another interviewee from Horn of Africa Regional Environmental Center and Network explained how the low level of commitment of officials of different sectors is preventing them from mobilizing adequate resources for the awareness creation activities, mutual discussion forums, and River Day celebrations.

Even though we have specifically planned to organize different resources from different sectors for printing and distributing posters and brochures on 35 different river issues, and magazines, officials were not committed to quickly provide the required resources on time. Even some sectors do not respond to our formal requests though we have made repeated letter of requests (Interview 24 28/04/2017).

During the direct observation, it was noticed that when selected students from different schools were taken to have a field visit to different rivers in Addis Ababa City, the collaborating sectors in collectively giving orientations, trainings and explanations were very few in number. The students were visiting rivers, assessing pollution status, and observing the vulnerability of rivers to human wastes.

As revealed by the data, the commitment of authorities to take part in evaluation forums and to follow up and ask their focal persons to make regular reports is very low as there are no adequate number of experts during field trips, the planned activities are not accomplished as scheduled, and follow-up activities are not prevalent. As a result, this is influencing the collaborative governance activities in that the required resources are not mobilized across sectors, trainings and guidance are not collaboratively given to the students, and river assessment activities are not collectively done as there is insufficient and delayed provision of information from other sectors. This is what Almeida et al. (2015) emphasized in his working paper that evaluation of collaboratively implemented activities is one of the central elements of collaborative governance activity.

\section{The random/non-criterion-based appointment of focal persons for the collaborative governance activity}

The collaborative activities of cleaning and protecting rivers are carried out through experts or professionals who represent different sectors and collaboratively work with other sectors in making river assessment activities, discussing on river problems, regularly following up river sites, and evaluating river protection tasks. Conversely, different sectors appoint persons who have no experience, expertise, or professional capability to engage in collaborative river governance activities. This is explained by the interviewee from the Addis Ababa Rivers and Riversides Project Office as follows:

During mutual discussion forums, the participant sectors are represented by individuals who lack experience and skill. Because of this the discussion process is dominated by some actors. Some of them are even randomly assigned, and at different occasions different individuals are assigned. However, we have observed that it is only few of them who actively suggest ideas and solutions (Interview 24/04/2017).

In a similar way, interviewees from other sectors explained that they do not have experts who have the experience with regard to dealing with river problems in a collaborative manner.

Institutionally speaking, we do not have any professionals or experts. And, this is not our mistake because there is no any system of employing or assigning river experts to deal with river problems. So, we assign individuals who are not busy at other activities or interested to represent the sector (Interview: 28/03/2017).

Actually, there is no a qualified expert in the area of environment to engage in river issues. What we do is that we assign such collaborative tasks to individuals who have some level of experience or exposure in different occasions (Interview: 09/05/2017). 
As the results of the study demonstrate, cross-sectoral collaborative governance activity is characterized by the representation of participant sectors by individuals who lack the required skill, expertise, or experience in the area of river. As a result, cross-sectoral collaborative governance activities are dominated by few sectors, particularly mutual discussion, supervision, and evaluation activities. This characteristic feature of collaborative governance is found out to be contrary to the basic principles espoused by Bryson et al. (2015). Bryson et al. (2015) noted that evaluative assessment activities in cross-sectoral activities should be considerate of the collaboration of all participant sectors in the process of implementation activities from the stand point of how the collaborative activity created a public benefit. However, the results of the study identified the existence of evaluation activities that are not considerate of the role of all sectors. Similarly, Morse and Stephens (2012) characterize the "competency" or the expertise or knowledge of participant actors in the collaborative governance activity as one basic component.

\section{Inadequate and no exchange of information}

One of the cross-sectoral collaborative governance activities is the exchange of information and data. Interviewees from the Addis Ababa Rivers, and Riversides Project Office explained the kind of information their sector is looking for during the pilot study and preliminary assessment of highly polluted and vulnerable rivers.

Actually, during the pilot study, we have required some list of information about the following issues;

1. The number of unemployed youths and women that could be employed at different river project sites.

2. The number of collaborative unions to take part in the river cleaning and protection activity. Collaborating unions are those self-organized and governmentfinanced cooperatives that have to be employed at different river sites.

3. We also look for the organized list of such unions.

However, in terms of obtaining such information, we have faced serious challenges because of the late response of the requested sectors. Even there are other sectors, which did not provide any data that we requested. Others provided data but that is inadequate (Interview: 26/04/2017).

On the other extreme, interviewees from Youth Association and Small and Micro Enterprise Bureau explained that they are requested to provide information without having mutual understanding of the issues.
Actually, they requested us to give them information about the number of unemployed women and youths. The activity requires some time and process of registration. Besides, the activity of giving information on such issues requires some kind bureaucracy in the sense that we have to first talk with other sectors and officials, particularly Women and Youth Bureau of Addis Ababa City Administration to make the accurate selection of these unemployed group of people. Even some times, though we request them(Addis Ababa Rivers, and Riversides Project Office Experts) back to give us some clarification of the agenda or issue, they either very lately respond to us or do not at all respond to us (Interview: 27/04/2017).

We were asked to organize and provide the list of unions that could be employed at different river sites. However, the criterions were not as such clear. Even though, we have tried to respond them back some more clarification about the issues, it seems that they are late in terms of giving us the detailed criterions to make the selection process (Interview: 27/03/2017).

The results of the study demonstrate that there is a problem of very weak exchange of information that is relevant for the river cleanup, protection, and conservation activities. One of the issues with regard to the exchange of information is lack of clear understanding among the collaborating sectors regarding what type of information and from whom to bring the required information. This resulted in the absence of adequate information for the river protection activities. Besides, the unwillingness nature of authorities of different sectors is another setback that delays the exchange of information. The other important issue with regard to the exchange of information is the bureaucracies that make the exchange of information very time taking.

\section{Lack of regular communications}

The other challenge of cross-sectoral collaborative governance activities is lack of regular communications to exchange feedbacks and evaluate the tasks and performances of the employed unions at different river sites. In this regard, it was well discussed during the discussion on the 100 K.M. $100 \mathrm{~m}$ River Cleaning and Protection Rally Project that the absence of regular schedules of having a face-to-face discussion forum is preventing them from well developing the mechanisms of collaboratively dealing with river problems and effectively implementing the action plans.

One of the challenges of our collaborative governance activity is that we are not having a regular communication forum. Particularly, after major discussions are held, most of the participant sectors do not meet again 
to evaluate their work plans, design better mechanisms of implementing action plans, and to make some more agreements on how to share resources, though there are weekly schedules (Direct Observation: 03/04/2017).

Actually, one of the challenges of cross-sectoral collaborations is that we do not meet again to jointly evaluate activities at river sites after we have some discussions on the project. This is preventing us from having a mutual platform to discuss and deal with other challenges that were experienced in the river sites (Interview: 03/05/2017).

Similarly, the absence of regular programs of having a discussion forum is one of the challenges of collaborative governance activity among sectors. Though there are weekly and monthly schedules, very few sectors took part in such platforms (100 K.M. 100 m River Cleaning, and Protection Rally Project Discussion Paper, 2017b).

On the other spectrum, interviewees from the other sector posited different reasons for not taking part in such regular schedules of discussions to examine draft plans, exchange feedbacks, and evaluate performances of unions at river sites.

Of course, we have not taken part in all regular programs. But the reason is that we do not have experts that could take the responsibility of participating in such programs (Interview: 04/05/2017).

We always expect formal invitations from the Addis Ababa Rivers, and Riversides Project Office to get some guidance. Therefore, we take part in those forums that we have been invited (Interview: 02/05/2017).

Regularly meeting and communicating in various aspects of river governance activities is one of the central issues in collaborative governance activity. In this regard, the involvement of sectors in such communications is not as such regular because some of them have no experts to take part in such programs. On the other hand, there are no regular schedules of communications on some of the river governance issues, such as evaluation of performances and discussion on reports made by the focal persons. Thus, such lack of regular schedules to take part in the evaluation of performances of employed unions and reports of focal persons for corrective measures influences the commitment and sense of responsibility of authorities of different sectors (Emerson et al. 2011; Rosemery 2014).

\section{Low level of community mobilization activities}

Cross-sectoral collaborative governance activities could not be effective and sustainable if the larger community is not mobilized to take part in the river cleaning up and protection activities. This mobilization activity requires enhancing the awareness and understanding of the community about the goals and specific benefits of this 100 K.M. 100 m River Clean up and Protection Rally Project activity through the organization of mutual consultation forums, the dissemination of information through various medias, and other activities. Interviewee from the Community Mobilization and Participation Agency admittedly explained that the number of community consultations and discussion forums that were held were very few, though mutually agreed as their basic responsibility. "We have already made action plan to mobilize community involvement and awareness creation programs; nevertheless, we have organized few discussion platforms" (Interview 28/04/2017).

In light of this, most of the respondents explained that very few community consultation activities have been carried out which created a set back on the collaborative activities of implementing river protection action plans.

When we were trying to implement the action plans at different river sites, we have faced some conflicts with the larger community who live around those rivers. One of the incidents was when we were posting some notices that prevent the disposing of wastes into the buffered zones of rivers. The community assumed we were trying to destruct their residence. Because of this the representatives or focal persons of some sectors have gone away fearing for their personal security (Interview: 03/05/2017).

Actually, we have already contacted sub city councils and House Construction and Development Bureau to relocate illegal settlers at the selected river sites. We were told the illegal settlers were relocated. But, when we go there were other settlers and new settlers. This has been creating a difficult situation from collaboratively working with other sectors. Because of this, focal persons became less engaged in such activities (Interview: 02/05/2017).

I think the problem is that community consultations are not yet adequately and intensively contacted on the very detailed objectives and action plans of the project activity at every level to create sense of ownership and responsibility (Interview: 27/03/2017).

During the discussion among the River, Riversides Development Project Management Boards in the Quarterly meeting, the participants have raised a number of points. They admitted that the engagement of the community is low, and this is creating a challenge in their collaborative governance activities in a number of ways.

Since such kinds of river cleaning and protection activities are directly related to the lives of the community, 
we should work more to involve the community so that we can make them important allies not resistances of the project activity (Addis Ababa Rivers, and Riversides Project office Management Board Discussion Report 2017a).

In order to achieve the objectives of cleaning and protecting rivers from various pollutions, illegal settlements and dumping of wastes, I think it is crucial to design some mechanisms of engaging the larger community in the activities. Particularly, since the people of low economic level are living around the community, we have to take careful steps to make them understand the benefit of such project, and convincing them that compensation and other benefits will be provided (ibid).

Since the community is not well consulted about this project activity, we will still experience more challenges. We cannot ensure the active involvement of other sectors in terms of assigning focal persons and providing resources unless we first engage in consultation process with the community (ibid).

Besides, the community is not well consulted at all levels in a more organized manner about the details of the prepared plans. The community has not been given the opportunity to evaluate the activities done at different river sites (ibid).

Though a total of 10 community consultation programs were organized, $50 \%$ of the planned activity was accomplished (Addis Ababa Rivers, and Riversides Project Office Annual Report 2017c). Therefore, community engagement mechanisms are not adequately conducted, and this is creating a challenge during the implementation activities of river cleanup and protection tasks.

On the other hand, interviewee from Community Consultation and Participation Agency explained the problem of lack of strong community mobilization activity from the following view point.

Well, of course the level of community engagement is low. However, the problem is that the context of organizing a forum to discuss with the community about draft plans and evaluation of activities is suitable. We require the collaboration of different sub cities to assign professionals to help us. Besides, we also need some organized information about the community to make a list and organization of schedules. But, the responses of other sectors are not encouraging as they do not respond to our requests nor interested to work with us (Interview: 28/04/2017).

As the results of the study demonstrate, the community as one important partner in the collaborative governance activity is not well incorporated. This is because there are no community organizations or board that could representatively work on behalf of the community with regard to river problems. The fact that different sectors do not accomplish their responsibility of organizing community consultation platform and community participation councils inhibits the collaboration of the community in a meaningful manner. Apart from facilitative styles emphasized by Sutcliffe (2012) and Sophia and Mark (2006) as important to encourage the participation of sectors and exchange of information, this study found out that the acceptance or recognition of the letters of invitations from the organizers also affects the involvement of sectors. Thus, the community needs to be consulted to create a collaborative system among various members of the community.

\section{Low level of cross-sectoral collaborations in the implementation activities}

The other basic challenge of cross-sectoral collaborative governance activities is that after discussions and mutual consultations are made, sectors do not actively take part to implement the developed action plans. Collaborative governance activities in the implementation stage involve the practice of collectively providing trainings, mobilizing the required resources, assigning focal persons to supervise river sites, and regularly meeting to discuss on the activities done. In this regard, there is low level of cross-sectoral collaborative governance activity. When asked about the level of collaboration of other sectors in the implementation activities, particularly in organizing and deploying the employed unions, dividing tasks among various unions at different sites, interviewees explained the following.

One of the basic problems is that we request other sectors to organize unemployed women and youth to be employed at different river sites. After they provide us those lists which are provided very lately, collaborating sectors do not assign any focal persons to supervise and guide the activities of employed persons (Interviewee: 02/05/2017).

Some sectors assign focal persons that could supervise and guide the employed unions at different river sites. However the problem is that such focal persons are not professionals or lack expertise with regard to such issues. As a result of this, they always report cases of disagreements and misunderstandings to our office very repeatedly rather than handling them themselves (Interviewee: 03/05/2017).

On the other hand, the preparation of weekly and monthly work plans or facilitating the condition for the unions to prepare action plans themselves is not well done as other sectors 
do not take an active part (100 K.M. 100 m River Cleaning, and Protection Rally Project Discussion Paper 2017b). Besides, the interviewee noted how the lack of work plan for all employed Unions is creating disagreements among unions.

Though we have signed a mutual term of agreement to work together with different sectors, their collaboration in the implementation activities is very low. The preparation of monthly work plans that are based on the action plans is always conducted by the Addis Ababa Rivers, and Riversides Project Office, for other sectors are not interested and did not respond to our request for these tasks. Actually, there are some tasks of preparing daily, weekly and monthly work plans for the employed Unions. Besides, there is no any collaboration from other sectors in terms of preparing such work plans for all employed Unions to create a uniformity and consistency among the Unions in terms of timely achieving the desired goals. Besides, different unions are not provided with a uniform payment manual which is creating conflict and competition (Interview: 03/05/2017).

In addition to this, the other challenge of collaborative activity among sectors is with regard to daily follow-up, guidance, and evaluation and reporting of activities done at different river sites.

Well, the level of participation of woreda level sectors is very low in regularly following up and guiding the activities of employed unions at different sites. It is becoming very difficult for our office to carry out this task it requires assigning more experts and focal persons (Interview: 26/04/2017).

Of course, our regular program of following up the activities of employed unions is not well scheduled. Other sectors are not assigning experts and focal persons to carry out this task nearly and daily (Interview: 17/04/2017).

There is no as such any system of conducting a regular evaluation and reporting tasks accomplished at different sites. This is constraining us from working more jointly. There is no understanding of how to conduct such activities (Interview: 05/05/2017).

In a similar way, the discussion paper of Addis Ababa Rivers, and Riversides Project Office explained it as follows:

There are certain major challenges of cross-sectoral collaborative governance activities. These are listed as follows.

A. Lack of Evaluation and report program of tasks done at different river sites.
B. Inconsistencies of supervision activity schedules of Addis Ababa Rivers, and Riversides Project Office.

C. Payments are not made based on the level of accomplishment of unions. And, there is also no participation of other sectors, particularly woreda sectors in preparing this and giving to all unions.

D. The work plans of different employed unions are not prepared by the other responsible sectors, creating a huge burden on the Addis Ababa Rivers, and Riversides Project Office.

All these are the major challenges that created difficult situation for cross-sectoral collaborative governance activity. This is because, focal persons have no any knowledge or experience of such activities, and authorities of sectors are not committed to regularly engage in such activities. The participant sectors are not implementing the terms of agreements to work together (Addis Ababa Rivers, and Riversides Project Office 100 K.M. 100 m River Cleaning, and Protection Rally Discussion paper 2017b).

On the other hand, interviewees from other sectors explained that apart from providing resources, it is not their responsibility to prepare work plans.

We have already provided the required resources, such cars, finances, and etc. so, we cannot engage in such detailed activities of supervising, evaluating or providing guidance of the employed unions (Interview: 17/07/2017).

What can we do? Our sector is collaborating by giving the required resources. The other is not our responsibility (Interview: 28/03/2017).

The results of the study show that the collaboration of sectors is challenged by the lack of sectors' involvement in the implementation of action plans in different river sites. One of the points is that the terms of agreements to work together are not strong enough to bring sectors in the implementation activities. This is opposite to the statement made by Bryson et al. (2015) that sectors have to engage in mutual terms of agreements that have "authoritative texts" which means that the mutually agreed principles have to be legalized and made all the signing sectors legally responsible to implement in a collaborative manner. Ansell and Gash (2007) explained that in collaborative governance activity, all the participant sectors "own" the process of working together: deliberating, being committed to share resources, and implementing collectively developed action plans. Nevertheless, collaborative governance of Addis Ababa Rivers involves very limited involvement of sectors which is a clear mark of the fact that the process of collaborative governance is not shared by all participant sectors, which is found to be 
one of the characteristics of collaboration in the other section of this study.

\section{The practice of corruption during selection and organization of unions, and women and youth}

Corruption refers to the practice of manipulating or using public responsibility for personal gains or benefits (Guillermo and André 2017). It greatly affects the activities of cross-sectoral collaborative activities by creating disagreement. One of the collaborative governance activities is the selection and organization of different women and youth to be employed in the river cleaning, protection, and conservation activities on the basis of the criteria set in the mutual discussion forum. However, interviewees explained that authorities responsible for this activity are not doing the selection and organization activity on the basis of the criteria and this is creating some level of difficulty in having a mutual understanding and agreement on the tasks to be done.

Actually, we have already set some criteria which are essential to select and organize youth and women, and also to select already organized Unions that could accomplish the tasks of cleaning and protecting rivers. However, it is not being done based on the criteria. There has been some kind favoring some unions. So, we are having some disagreement with such officials. (Interview: 02/05/2017).

We are facing difficulties with regard to getting a well-organized list of women and youths and unions to carry out our plan of cleaning and protecting rivers in an effective manner. This is because the responsible sectors are corrupted in this regard. We have been dealing with disagreements and repeated complaints from other non-selected Unions. Therefore, we are trying to deal with the matter ourselves. But the responsible sectors are not doing what we expected. Now, they are not alright with our activity as we are making some reselection of the rejected ones (Interview: 03/05/2017).

Similarly, during observation, it was noticed that the issue of favoring some unions and excluding others has been one of the discussion agendas (Direct Observation 2017). While some of the excluded unions fulfill the requirements, they are not selected; at the same time, some of the selected unions do not qualify the requirements, and they are poorly functioning (Addis Ababa Rivers, and Riversides Project Office 100 K.M. 100 m River Cleaning, and Protection Rally Discussion paper 2017b). Conversely, interviewees from other sectors explained that some unions are not selected because of their lateness to submit their application on time, and others do not completely fulfill the requirements (Interview: 27/03/2017).

As the results of the study demonstrate, the behavior of authorities who were given the responsibility to select, organize, and deploy unemployed unions, youth, and women at different river sites is a challenge for cross-sectoral collaborative governance activity. Apart from what Emerson et al. (2011) identified about how the communicative and participatory skills of representatives of sectors affect the process of collaborative governance activities, this study has also found out the rent-seeking behavior of responsible officials as one other challenge. This has created lack of legitimacy or acceptability of collaborative governance activities among the collaborating sectors, for some sectors do not govern on the basis of collectively developed principles and engage in corruption activities to obtain personal benefits. Therefore, legitimacy is not influenced only by how inclusive of different sectors and how the interest of different sectors is incorporated in the collaborative governance activity as explained by Bryson et al. (2015). It is also determined by the behavior of representatives of different sectors in governing on the basis of collectively developed principles.

\section{Low level of commitment to engage in mutual terms of agreements and knowledge sharing activities}

Mutual terms of agreements refer to the common guiding principles that explain how different sectors collaboratively work in governing river protection activities. This includes sharing of resources, their responsibilities, regular meetings to make evaluations of their activities, etc. Interviewee explained that authorities of different sectors are not committed to engage in such kinds of activities.

We have actually planned to sign a common term of agreement with a total of 11 sectors. Though we have repeatedly communicated them, only five of them come into agreements to have a common term of agreement (Interview: 03/05/2017).

Actually, our effort to discuss with them about the components of the terms of agreements has failed because of lack of willingness from authorities of different sectors. They do not reply to our request, nor give us any form of consent to discuss on the terms of agreements and share them together (Interview: 03/05/2017).

Similarly, reports from the Addis Ababa Rivers, and Riversides Project Office state about the engagement of other sectors to have a common term of agreement.

Goal 20.1 Establishing collaborative governance structure with different key sectors; 
11 main sectors were identified to have them as signatories of term of agreements. The task was $100 \%$ accomplished

A term of agreement has been prepared in a matrix form for all 11 identified sectors. This was also $100 \%$ accomplished.

However, only five of them were committed to sign the agreements. Therefore, the task was accomplished at $55 \%$ level. This was because of lack of commitment and willingness on the part of responsible authorities of other sectors though the project office tried to contact them many times (Addis Ababa Rivers, and Riversides Project Office Annual Evaluation Report 2017c).

The other form of collaborative governance activity is the sharing of knowledge to collectively examine and evaluate the appropriateness and context of draft plans that are intended to guide the practice of river cleanup and protection projects. The following note from the annual report of Addis Ababa Rivers, and Riversides Project Office explains this as follows.

\section{Goal 23. Developing the Legal Basis of Draft Plans}

Draft plan that guides the process of river clean up, protection and development activity has been accomplished at $100 \%$ level. In the same way, the draft plan has incorporated the interests of some voluntary sectors. However, the draft plan is not yet ratified because of the very tiresome bureaucracy of other responsible sectors (Addis Ababa Rivers, and Riversides Project Office Annual Evaluation Report 2017c).

The results of the study reveal that lack of commitment of the authorities of different sectors is an obstacle for crosssectoral collaborative governance activity. Because collaborative governance activity is guided by mutual terms of agreements that specify the forms of interactions, the respective responsibilities of each sector, how collective activities of implementing action plans are conducted and other tasks, low level of commitment from other sectors creates a setback from having an agreement and working together on various tasks. Bryson et al. (2015) explained that mutual term of agreements among the collaborating sectors is the key to create commitment, sense of responsibility, and sense of ownership on the part of other authorities of other sectors. In contrary to this, it is found out that because of the lack of commitment of other authorities and the bureaucratic systems, terms of agreements are not signed among sectors. This has effect in the later stages of collaborative governance activities as Emerson et al. (2011) noted. Emerson et al. (2011) noted that initial agreements and understandings are crucial to build the "capacity" of the collaborating sectors to engage into actions, such as mobilization of resources, supervision of river sites, regular evaluation of activities. The absence of mutual terms of agreements influences the creation of a collaborative capacity through sharing of resources in the implementation of action plans.

\section{The exclusion of river agendas from the annual plans of sectors}

As urban rivers are losing their natural quality as a result of a variety of factors that emerge from different contexts, the collaboration of other sectors is crucial in terms of incorporating rivers as one of their annual plans. Interviewee from Environmental Protection Authority of Addis Ababa expressed that rivers are not considered when annual plans are prepared.

You know what; the Addis Ababa City Council has a list of thematic areas that are designed to be conducted in collaboration with other sectors. Unfortunately and surprisingly, rivers are neglected in the list of such major areas of work intended to be accomplished in the city. Because of that we faced serious challenge from other sectors to make intensive information sharing, to get the initiation of other sectors, and to share resources (Interview: 03/05/2017).

What is very surprising to me is that while different sectors, such as Health Bureau, Addis Ababa Water and Sewerage Authority, and Land Management Bureau are responsible, in one way or another, to the problem of rivers, they do not feel responsible to such environmental issues. They do not include river issues as their basic annual activity (Interview: 18/04/2017).

The results of the study demonstrate that sectoral interest for collaborative governance activities is influenced not just by the institutional structures, the absence of appointed experts in the area of river as discussed in the other section of the study, but also by the exclusion of river in the annual plans of sectors. This is because the exclusion of river from the areas of concerns of sectors creates no sense of commitment and responsibility to engage in collaborative governance activities to deal with river problems. Apart from what Vodden (2015) discussed about the existence of limited level of shared responsibility, as some sectors do not actively take part in collective activities, the results of this study also found out that the planned tasks cannot be accomplished 
completely by some sectors alone when the responsibility of accomplishing collaborative governance activity is not shared by all sectors.

\section{The outcomes of low level of cross-sectoral collaboration on the Addis Ababa Rivers}

The existence of a low level of cross-sectoral collaboration among various stakeholders has created a multitude of problems on Addis Abba Rivers, in terms of river discharge and water quality. An assessment of the report made by the Addis Ababa Rivers, and Riversides Climate Change Adaptation Project Office reveals a variety of problems that are being observed across the Addis Ababa Rivers. Weak crosssectoral collaboration is creating a serious impact on the quality of the water sources which are being utilized by the agriculturalists around the city (Interview: 04/05/2017). The following picture shows the level of pollution that is being created on the quality of rivers (Fig. 3).

The wastewater collection and sanitation in Addis Ababa City is very weak, thereby creating a multiplicity of problems that are expressed in terms of the dumping of various wastes from all responsible organs, private business groups, industries, hotels, government organizations, households, and hospitals as well (Addis Ababa Rivers, Riversides Climate Change Adaptation Project Office, 2017a, b, c). The following table provides a very good representative evidence of how the Addis Ababa Rivers are deteriorating in terms of their quality as a result of lack of control on and collaboration from the industries (Table 1).

The table demonstrates the level of pollution that is being created from the different industries that are operational in
Table 1 A table that describes the level of industrial pollution that is created on the Addis Ababa Rivers Source Leta et al. (2016)

\begin{tabular}{lrr}
\hline Type of industry & $\begin{array}{l}\text { Quantity of wastewater } \\
\left(\mathrm{m}^{3} / \text { year }\right)\end{array}$ & $\begin{array}{l}\text { Percent } \\
\text { from the } \\
\text { total }\end{array}$ \\
\hline Iron and steal & 146,239 & 3.0 \\
Nonferrous metals & 2,227 & 0.0 \\
Food and beverages & $1,795,252$ & 36.8 \\
Paper and printing & 45,967 & 0.9 \\
Petrochemicals & 11,422 & 0.2 \\
Rubber & 205,746 & 4.2 \\
Pharmaceuticals & 50,089 & 1.0 \\
Soap and detergents & 1,089 & 0.0 \\
Tobacco & 31,080 & 0.6 \\
Textiles & $1,992,597$ & 40.9 \\
Leather and footwear & 547,860 & 11.2 \\
Wood & 47,805 & 1.0 \\
Total & $4,877,362$ & 100.0 \\
\hline
\end{tabular}

Addis Ababa City. The lack of strong collaboration among various stakeholders, particularly the collaboration of industries with other sectors, is now a major problem and threat for the city as there lacks a system of supervision and strong environmental impact assessment mechanism over industries.

During the interview with the Addis Ababa Rivers, and Riversides Climate Change Adaptation Project Office, the director has made the following notable comment.
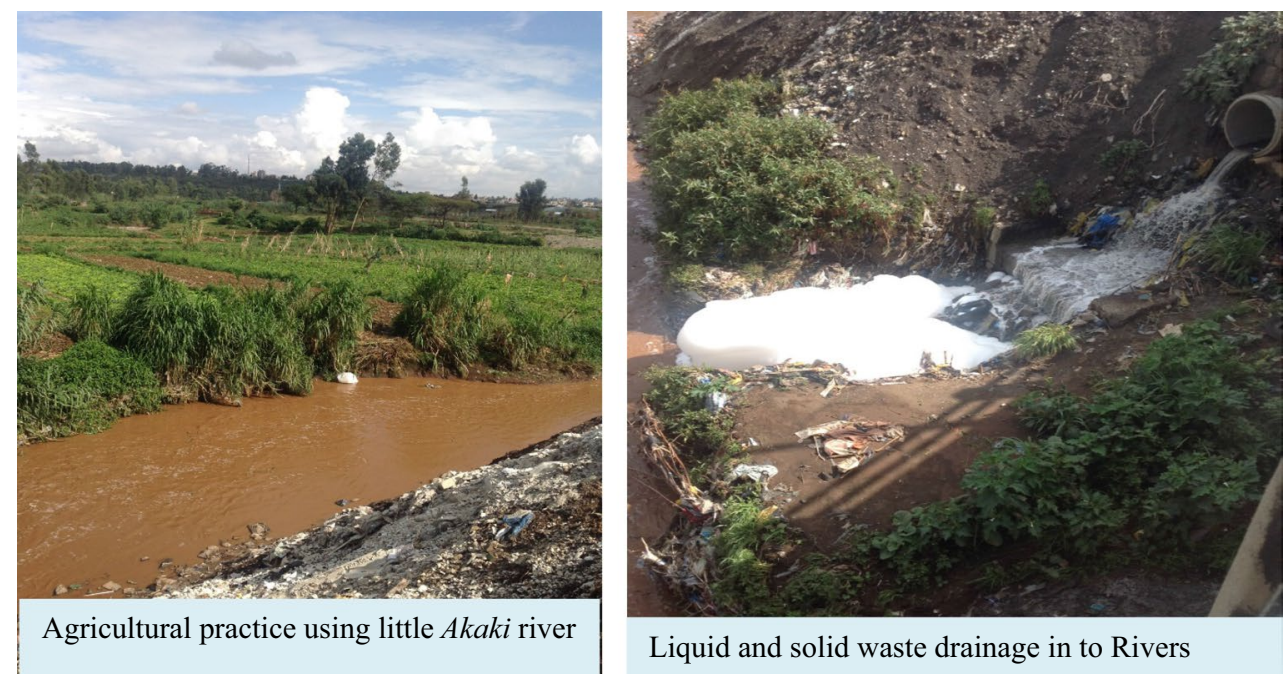

Source: Addis Ababa Rivers, Riversides Climate Change Adaptation Project Office, 2018

Fig. 3 A picture that demonstrates about how low level of collaboration among various sectors created environmental hazard to the riverside vegetation and agricultural activities. Source Addis Ababa Rivers, Riversides Climate Change Adaptation Project Office, 2018 
ADDIS ABABA CITY RIVER AND RIVER SIDES DEVELOPEMNT BKKK STUDY LOCATION MAP

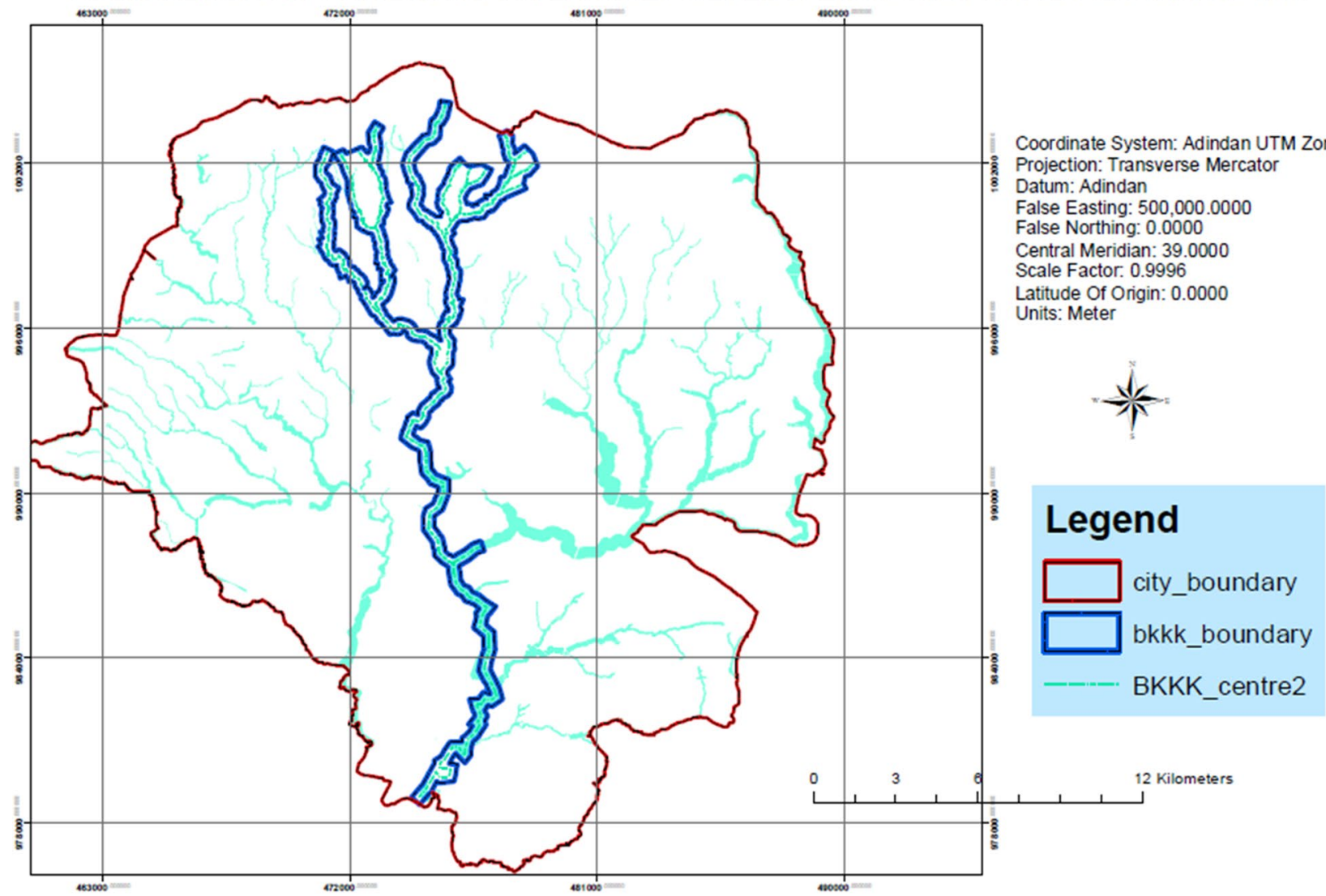

Fig. 4 Addis Ababa River and riversides development BKK+K study area. Source Addis Ababa City Rivers Riversides Development Project Office $2017 \mathrm{a}$, b, c

Actually, because we are not getting the collaboration of authorities and owners of different industries, we are facing a very disastrous realty. The amount of waste discharge that is being dumped into the rivers is very high. This is creating its own formidable impact on the rivers' quality. Many of the rivers, though appear to be a major source of livelihood for farmers and other stakeholders, are losing their natural quality and their level of utility for various purposes is declining (Interview: 05/08/2017).
Another interview from Environmental Protection Authority noted the following

It is difficult to get the agreement and consensus of sectors to work together to protect rivers. Particularly, authorities of industries do not agree to what we propose and as a result of this we fail to establish common frameworks to do some activities. Consequently, the industrial wastes are leading to the worsening of river quality. Apart from industries, households and other 
ADDIS ABABA CITY RIVER AND RIVER SIDES DEVELOPEMNT BKKK STUDY RIVERS NAME

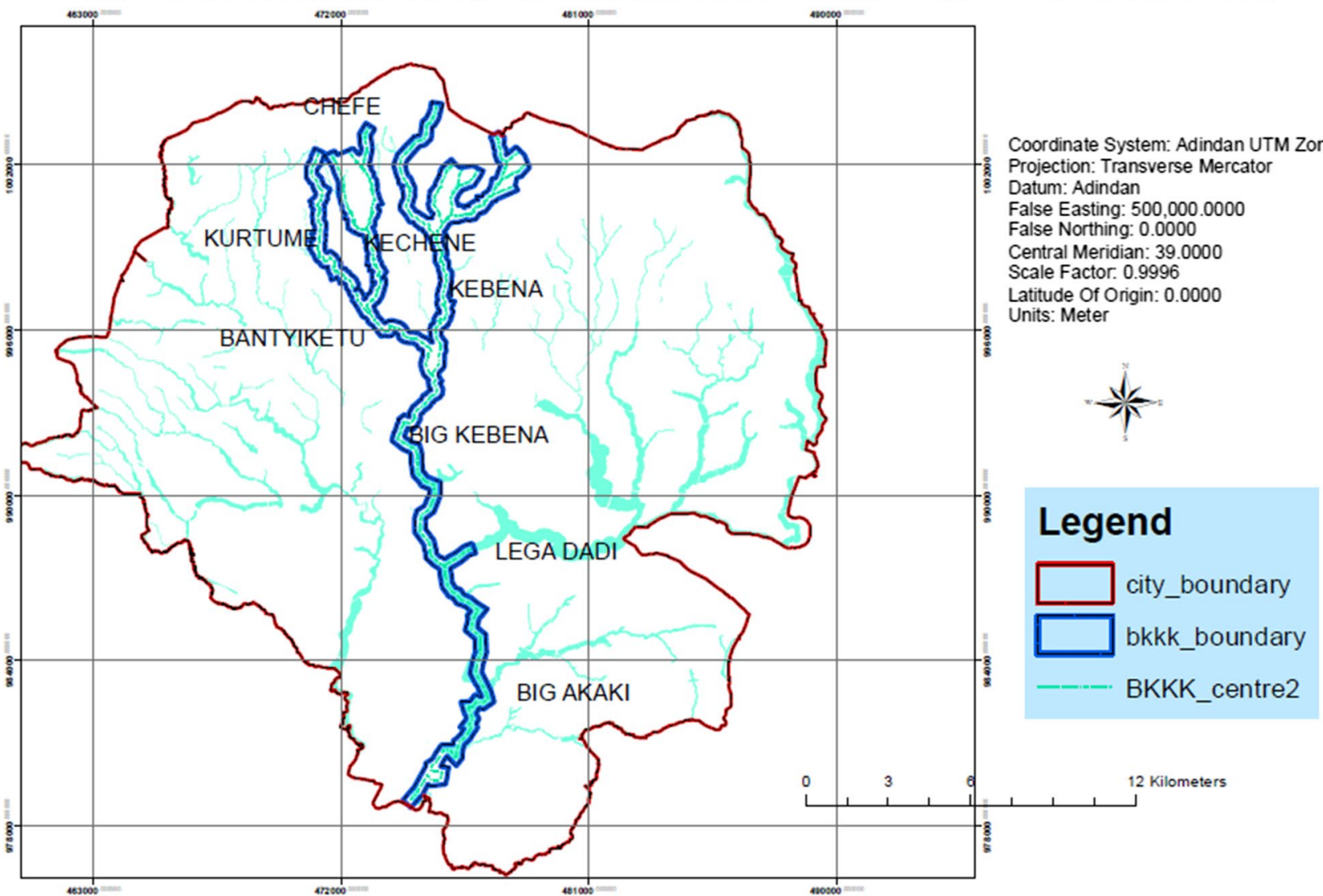

Fig. 5 Route of the rivers BKK +K. Source Addis Ababa Rivers, and Riversides Climate Change Adaptation Development Project Office, $2017 \mathrm{a}, \mathrm{b}, \mathrm{c}$

public organizations are also increasingly creating a problem on the river quality. These is all a result of the lack of collaboration of all responsible stakeholders (Interview: 02 03/05/2017).

Due to irresponsible waste disposal mechanism of responsible stakeholders, lack of cross-sectoral management and governance system, and other related factors, Addis Ababa Rivers are being polluted. The level of pollution that is being created on the Addis Ababa Rivers is now accelerating with the increasing pressure coming from the increasing number of households, illegal settlers, poorly assessed industries, and private business groups that are being built around rivers (Meklit et al. 2016).

\section{Conclusion}

The results show that there are a number of challenges in the activity of governing rivers in a collaborative manner. The first one is related to the commitment of responsible authorities of different sectors. Different authorities are not willing and committed to initiate, provide information, to assign experts, to provide feedbacks, and take part in discussion 
BKK River of Addis Ababa $1: 10,000$
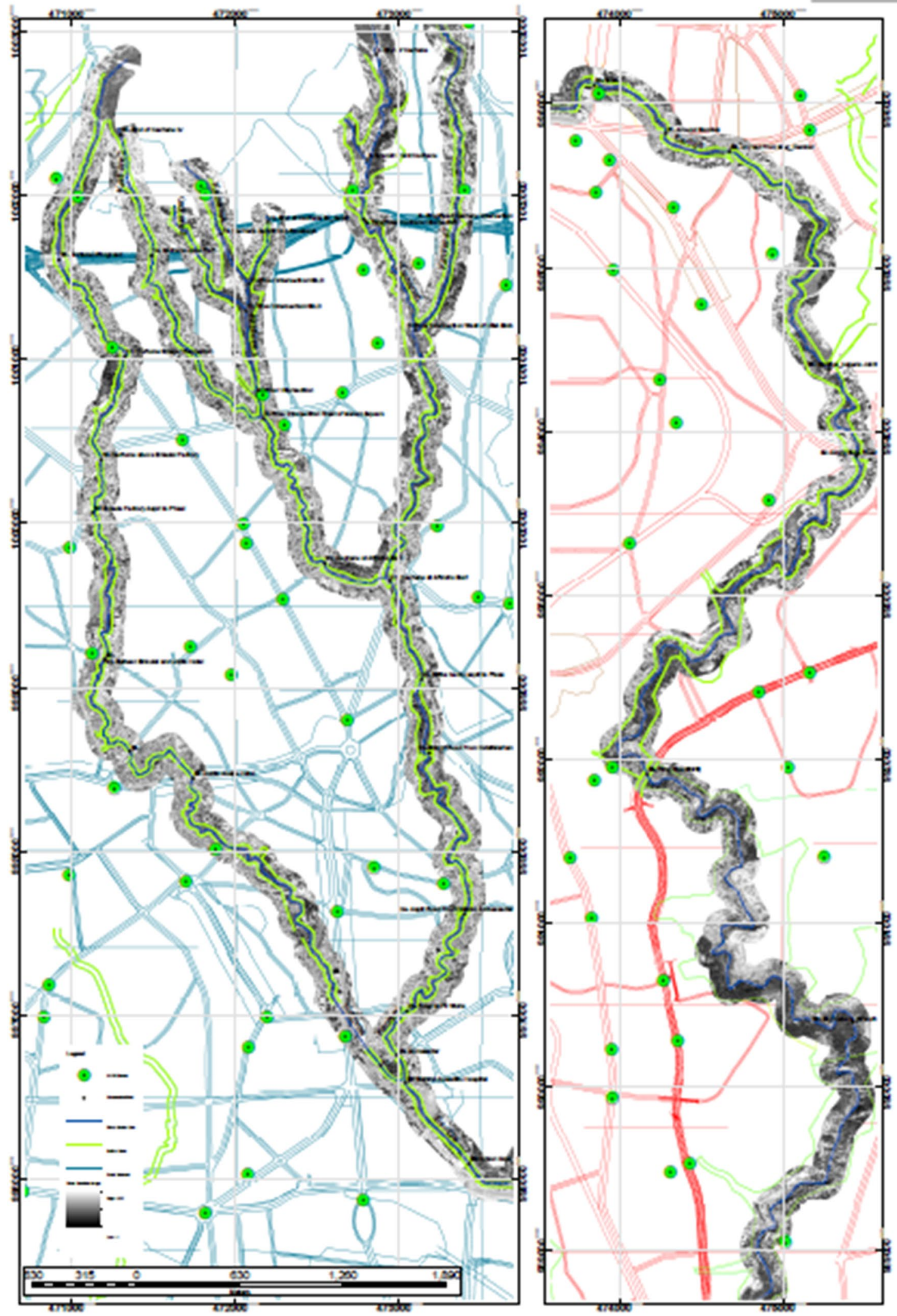

Fig. 6 The whole River Corridor with Road Network. Source Addis Ababa Rivers, Riversides Climate Change Adaptation Project Office 2017a, b, c $\checkmark$ 
Fig. 7 False color composite of the satellite images for the three time periods of Addis Ababa Rivers. Source Addis Ababa Rivers, and Riversides Climate Change Adaptation Project Office 2017a, b, c
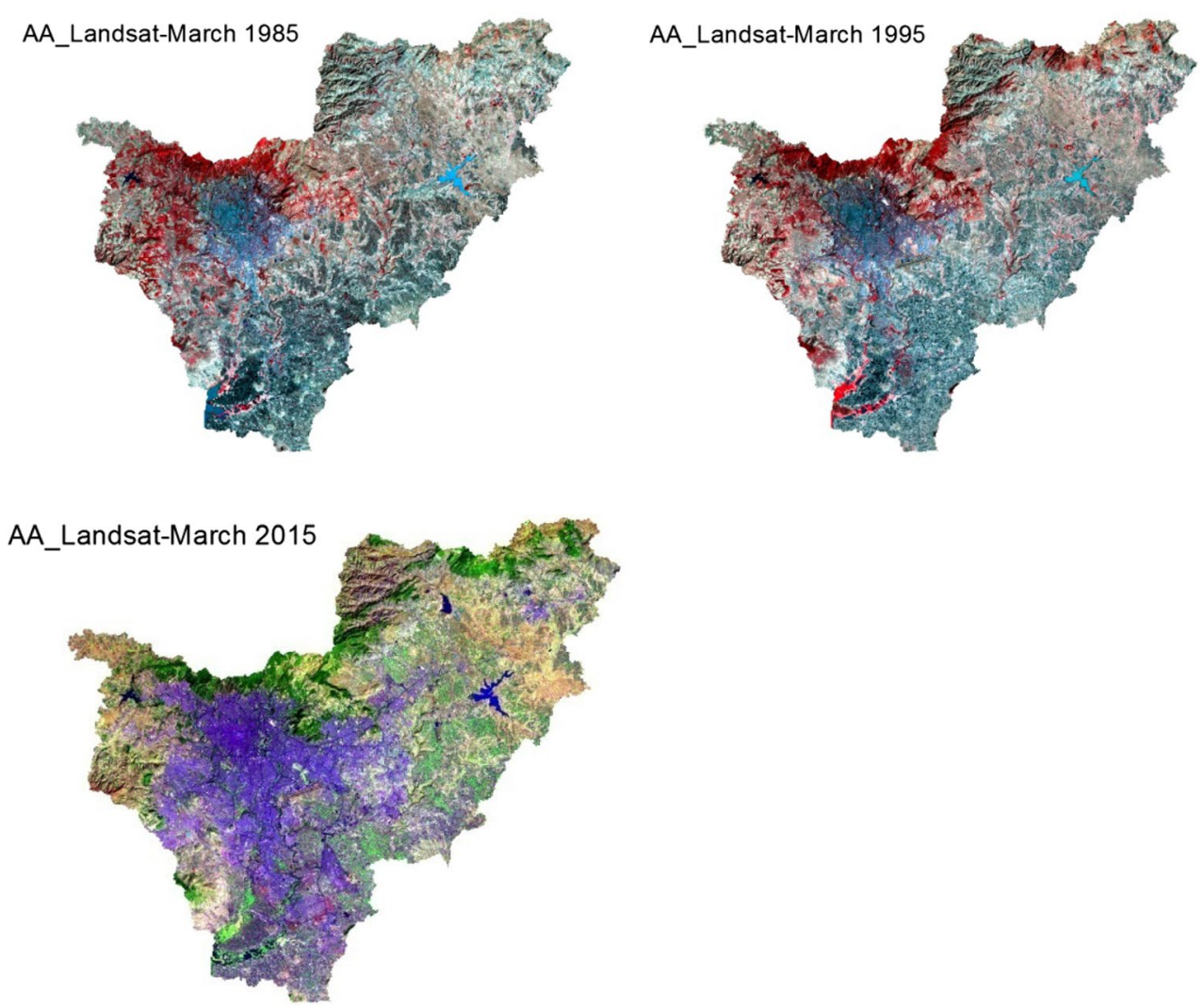

forums. Therefore, cross-sectoral collaborative governance activity is challenged by the lack of attention and focus from all sectors. It is considered the responsibility of few sectors alone. Thus, the behavior of authorities to give attention, be committed, and feel responsible for river problems is challenging the practice of collaboration among different sectors. Many of the participating and responsible authorities are providing a very lower level of concern for river problem, making river problem as nonessential. In addition to this, these set of river governance problems have created a huge pressure on the environmental safety of the residents of Addis Abba City and the surrounding areas. Therefore, unless river governance problems are effectively addressed, the utility of river resources in Addis Ababa City will be very minimal; and, it will continue to create a challenge over the health quality and environmental safety programs of various agencies (Figs. 4, 5, 6, 7, 8, 9, 10, 11, 12, 13 and 14).

The other challenge is related to the absence of experts. Most sectors do not have river expert and thus take it as a reason not to take part in the implementation activities of supervising and evaluating river sites. Because of this, most sectors do not well articulate their interest and give the required contribution in the river protection activity. Therefore, collaborative governance of rivers is constrained by the absence of experts from each sector that could responsibly take river as an agenda to be conducted in collaboration with other sectors. 

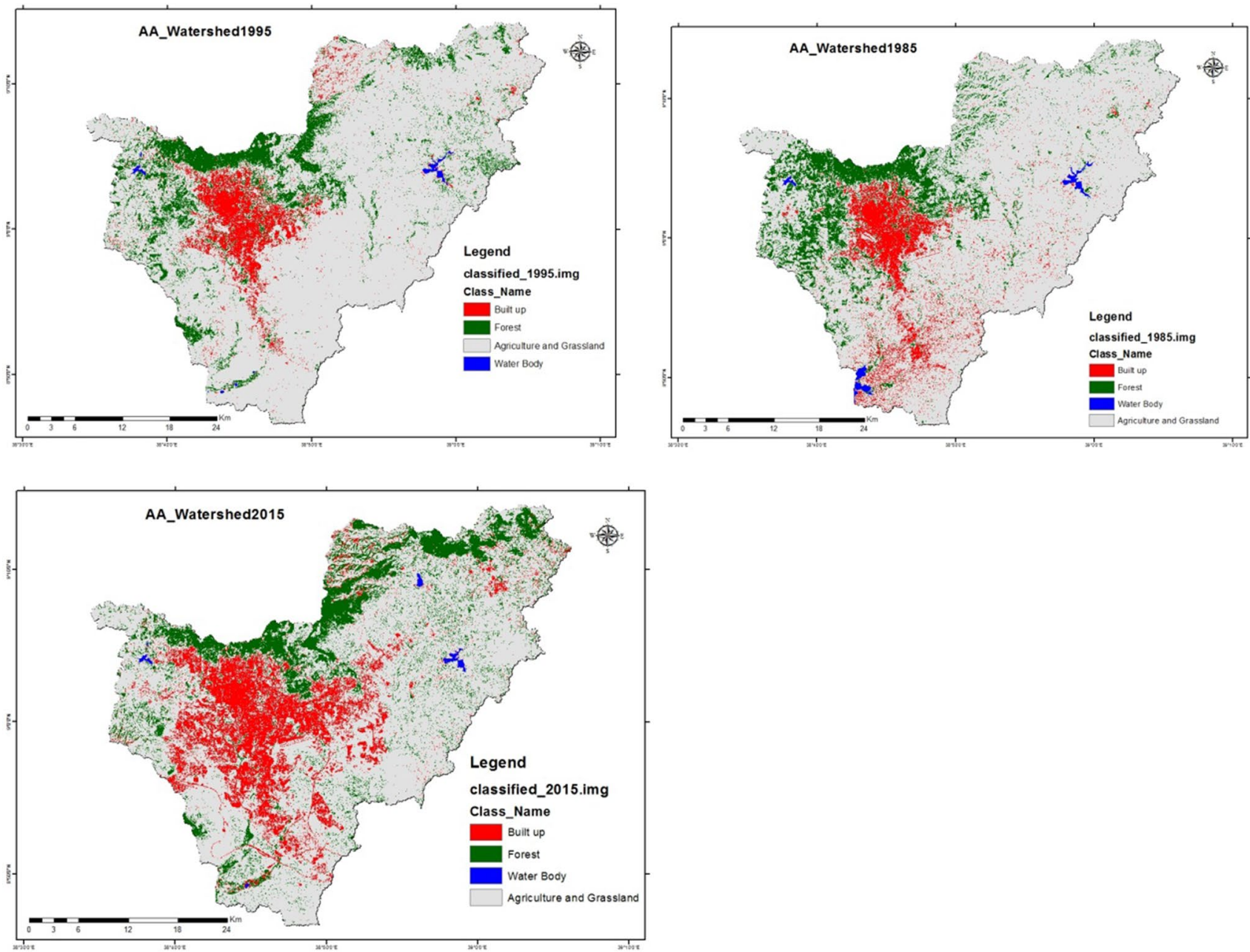

Fig. 8 Classified maps of land use and land cover of the major/large watershed of the Aba-Samuel reservoir. Source Addis Ababa Rivers, Riversides Climate Change Adaptation Project Office 2017a, b, c

Community mobilization is also another issue that is not carried out by all the responsible sectors, making the implementation activity very difficult and consultation with the community very challenging. Therefore, the absence of mobilizing the community into an organized structure prohibited communication, consultation, and collaboration with the community very difficult. This shows how much the collaborative governance activity is not based at the bottom and lacks one of the important actors to effectively carry out the collaborative governance activity. The involvement of 


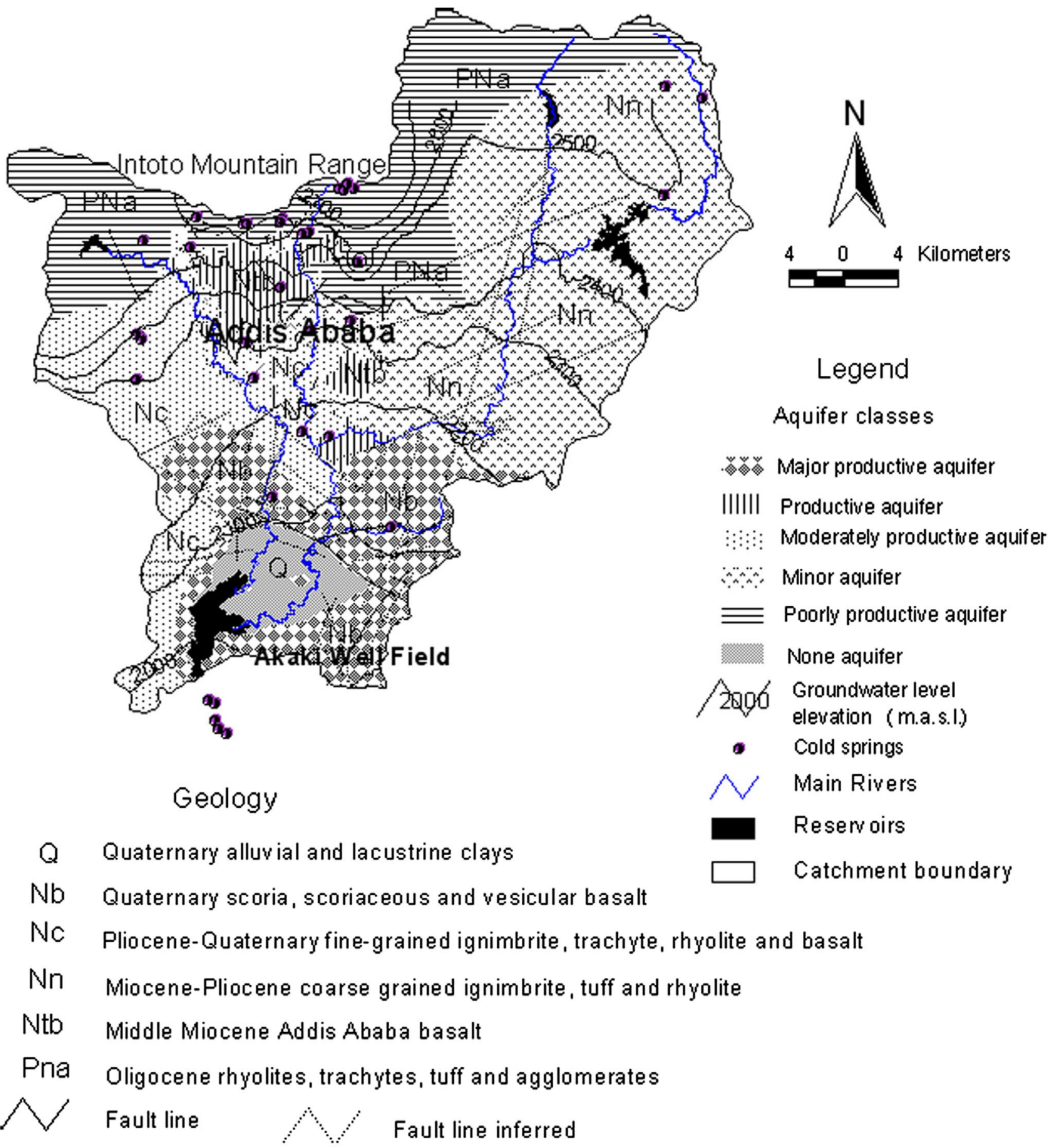

Fig. 9 Geology and hydrogeology map of the major/large watershed of the Aba-Samuel reservoir. Source Addis Ababa Rivers, and Riversides Climate Change Adaptation Project Office 2017a, b, c 


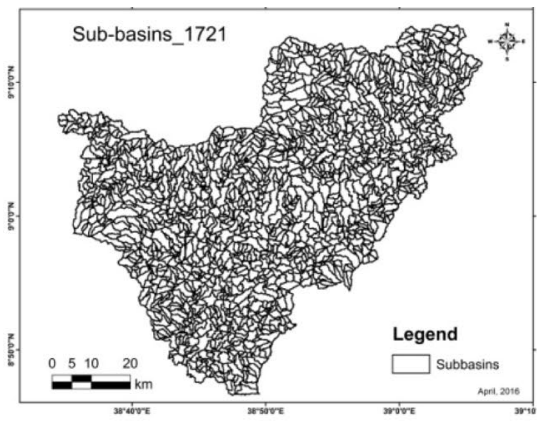

Micro-watershed map

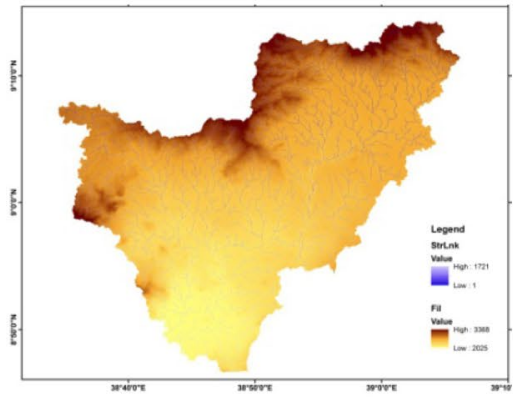

Stream segmentation map

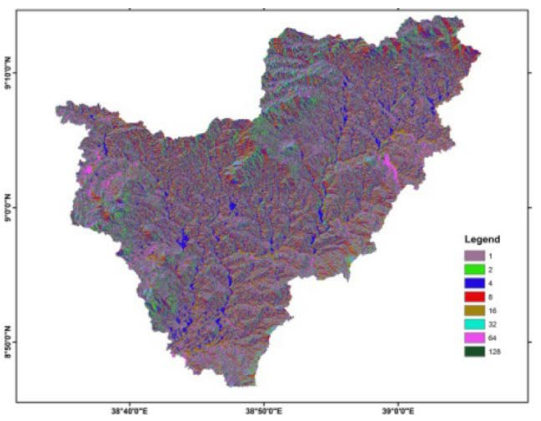

Flow direction map

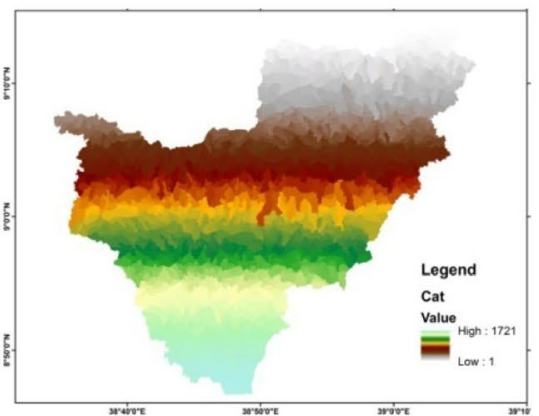

Catchment development map

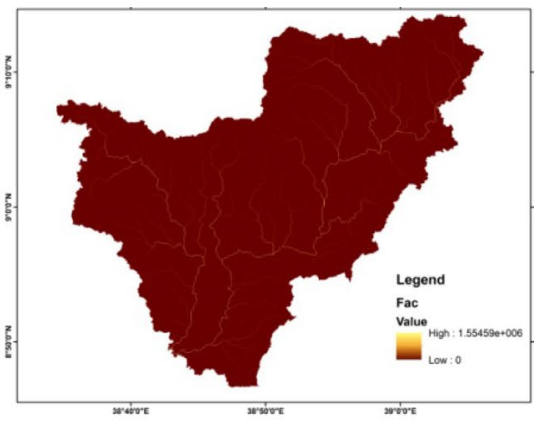

Flow accumulation map

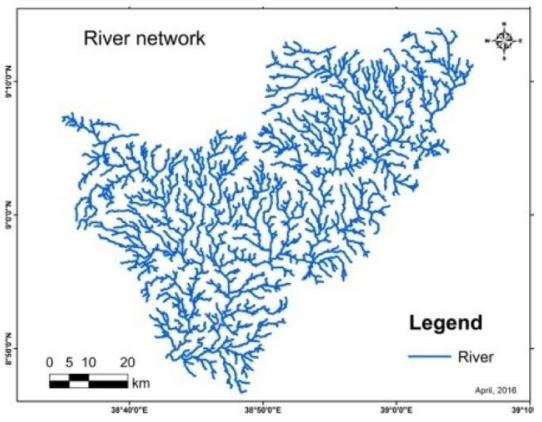

Stream network map

Fig. 10 Different parameter maps for the flood risk and runoff discharge. Source Addis Ababa Rivers, and Riversides Climate Change Adaptation Project Office 2017a, b, c

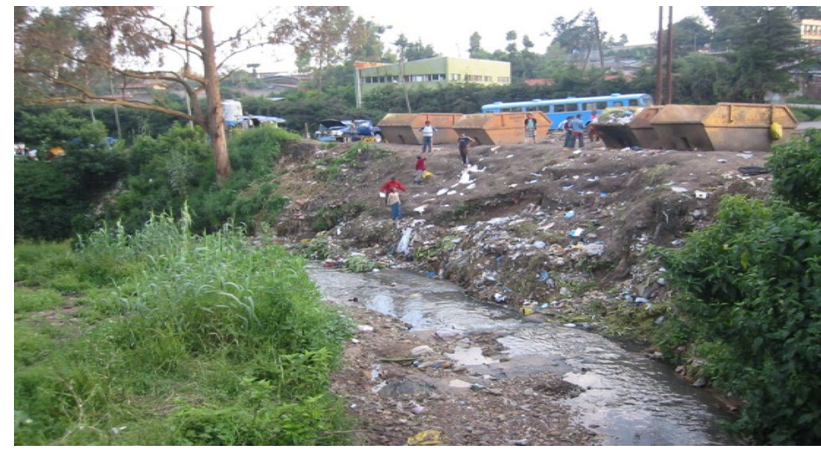

Fig. 11 Wastewater dumping along riversides by the road. Source Addis Ababa Rivers, and Riversides Climate Change Adaptation Project Office $2017 \mathrm{a}$, b, c the community and other private organizations is assumed to be unimportant (Tables 2 and 3).

The implementation activities of supervising river site unions, mobilizing resources, regularly organizing and sharing reports, and evaluating river site activities are not carried out by all sectors. Because of lack of willingness and focus from different sectors, many of the sectors do not actively take part in the post-deliberation implementation activities. Thus, the collaborative governance activity is challenged by the absence of strong sense of responsibility and attention from all sectors to collaborate throughout the whole process of protecting and conserving rivers.

The problem of weak cross-sectoral collaboration among various stakeholders is creating a huge array of problems on 


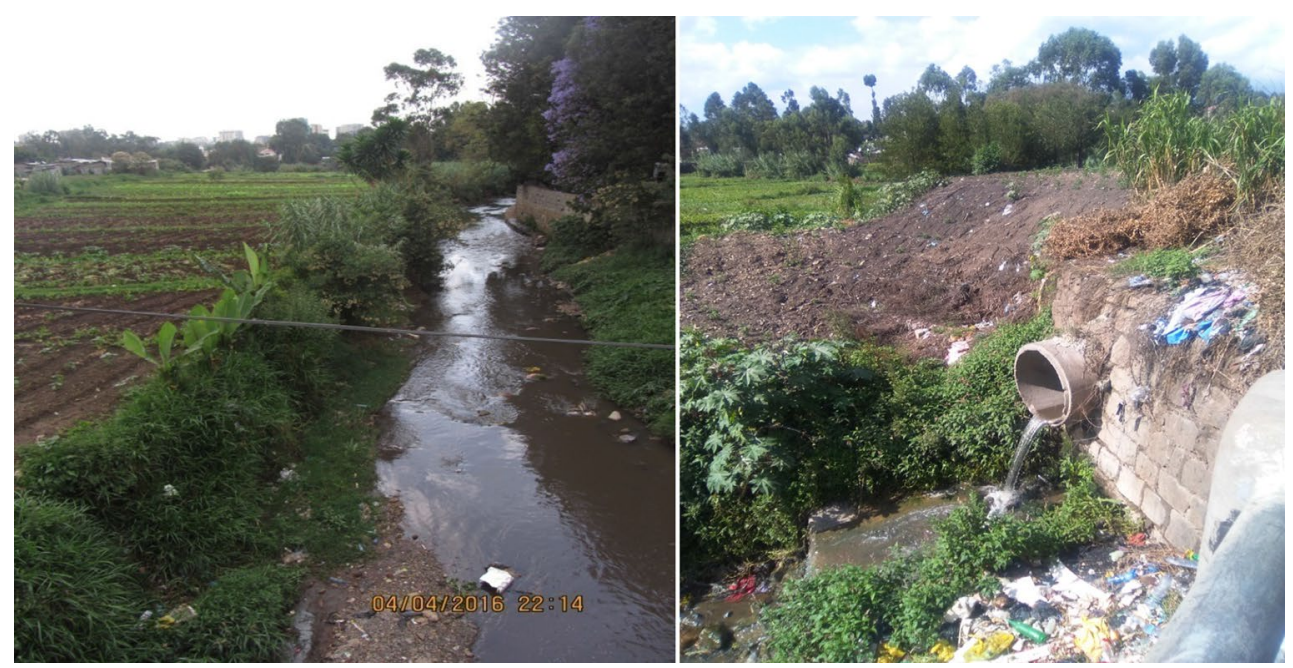

Fig. 12 Waste disposal and agricultural activities along Akaki River. Source Addis Ababa Rivers, and Riversides Climate Change Adaptation Project Office 2017a, b, c
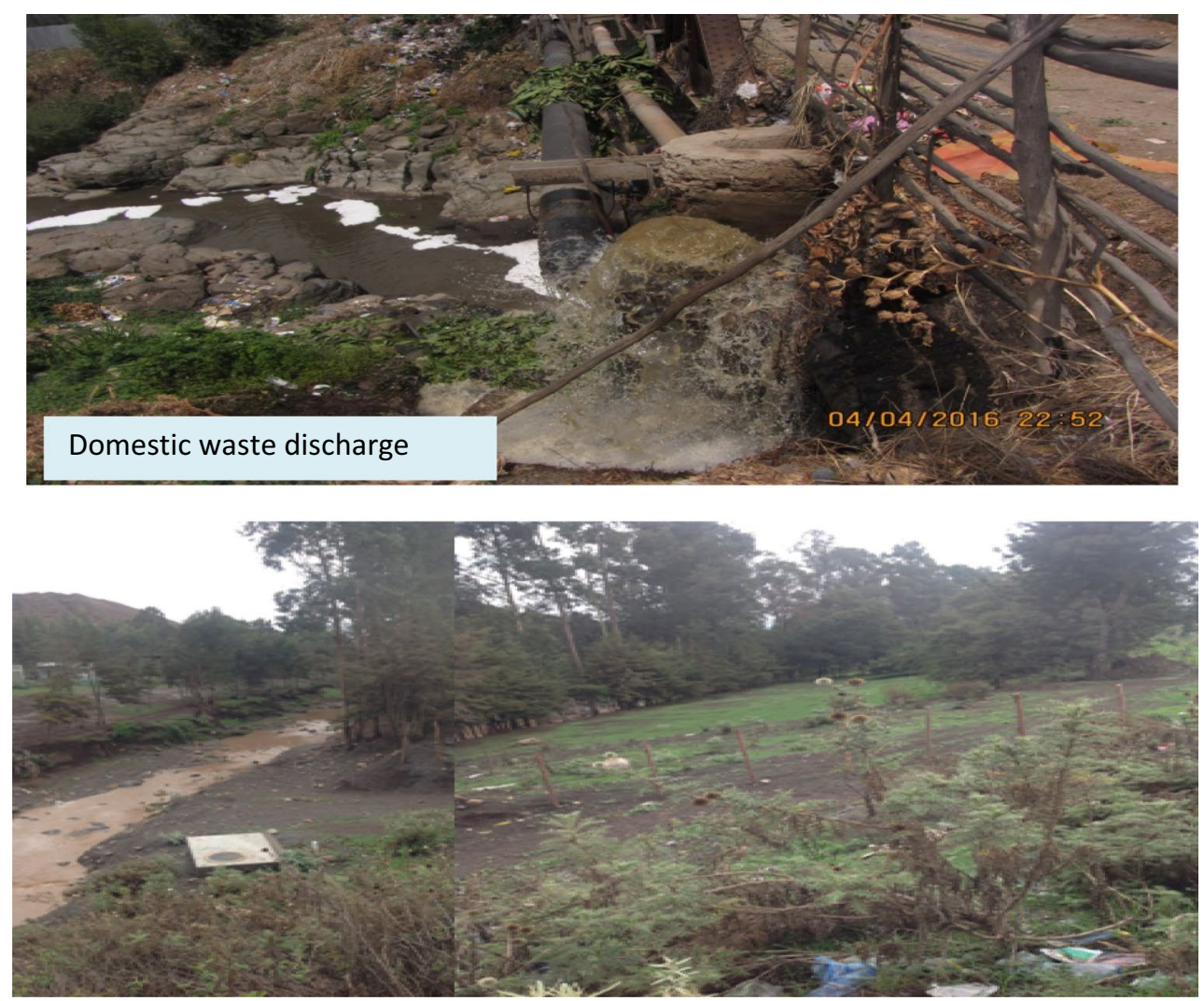

Fig. 13 Source, waste disposal, and potential recreational area along big Akaki River. Source Addis Ababa Rivers, and Riversides Climate Change Adaptation Project Office 2017a, b, c 

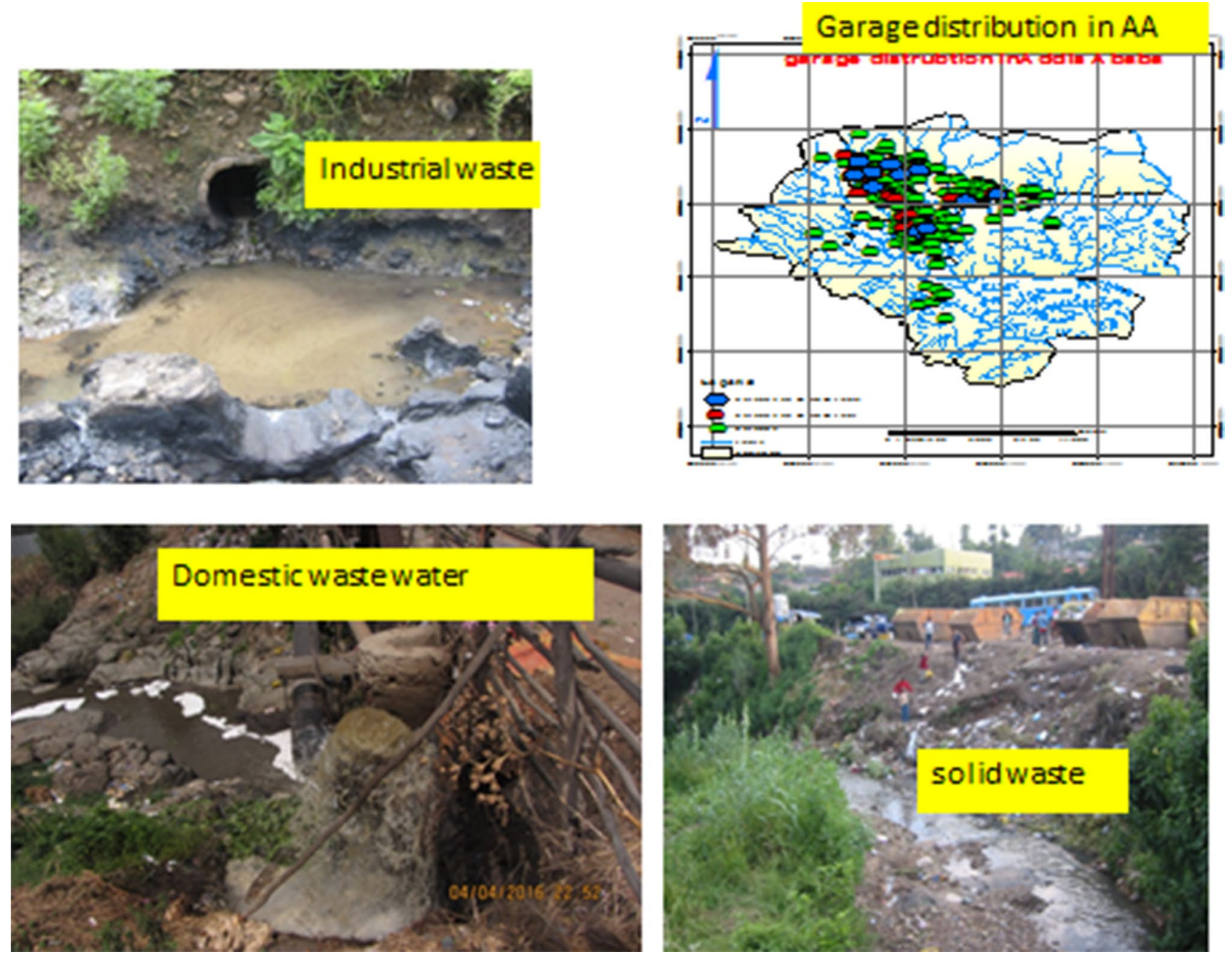

Fig. 14 Major industrial pollution observed during the field trip. Source Addis Ababa Environmental Protection Authority (2017)

river quality and discharge. The quality of the rivers that are flowing across the city is heavily affected in that the rivers change their color, level of utility, and create a hazardous impact on the ecosystem, affecting human and animal health, and disturbing the vegetation practices. Apart from these, the level of pollution that is being created from the increasing 
Table 2 The list of interviewees and their sector Source Protection Authority (2017) Addis Ababa Environmental

\begin{tabular}{|c|c|c|c|}
\hline No & List of interviewees' sector & Date of interview & Code \\
\hline 1 & $\begin{array}{l}\text { Addis Ababa Rivers, and Riversides Climate Change Adaptation Project } \\
\text { Office }\end{array}$ & $\begin{array}{l}26 / 04 / 2017 \\
02 / 05 / 2017\end{array}$ & $\begin{array}{l}0 \\
1\end{array}$ \\
\hline 2 & $\begin{array}{l}\text { Addis Ababa Rivers, and Riversides Climate Change Adaptation Project } \\
\text { Office }\end{array}$ & 03/05/2017 & $\begin{array}{l}0 \\
2\end{array}$ \\
\hline 3 & Addis Ababa Rivers, and Riversides Climate Adaptation Project Office & 03/05/2017 & 021 \\
\hline 4 & Gulele Botanic Garden of Addis Ababa City & $09 / 05 / 2017$ & 017 \\
\hline 5 & Water and Sewerage Authority of Addis Ababa City & $27 / 04 / 2017$ & $\begin{array}{l}0 \\
4\end{array}$ \\
\hline 6 & Planning Authority of Addis Ababa City & $21 / 04 / 2017$ & $\begin{array}{l}0 \\
5\end{array}$ \\
\hline 7 & Environmental Protection Authority of Addis Ababa City & $18 / 04 / 2017$ & $\begin{array}{l}0 \\
6\end{array}$ \\
\hline 8 & Environmental Protection Authority of Addis Ababa City & $19 / 04 / 2017$ & $\begin{array}{l}0 \\
7\end{array}$ \\
\hline 9 & Environmental Protection Authority of Addis Ababa City & $17 / 04 / 2017$ & $\begin{array}{l}0 \\
8\end{array}$ \\
\hline 10 & Education Bureau of Addis Ababa City & $28 / 04 / 2017$ & $\begin{array}{l}0 \\
9\end{array}$ \\
\hline 11 & LID Leather and Industrial Development Agency & 05/05/2017 & 012 \\
\hline 12 & Beautification and Open Green Space Area Bureau of Addis Ababa City & $02 / 05 / 2017$ & 014 \\
\hline 13 & Yeka Sub City of Addis Ababa City & $05 / 05 / 2017$ & 015 \\
\hline 14 & Nifas Silk Sub City of Addis Ababa City & $28 / 03 / 2017$ & 016 \\
\hline 15 & Gulele Sub City of Addis Ababa City & 09/05/2017 & 017 \\
\hline 16 & Lideta Sub City of Addis Ababa City & $02 / 05 / 2017$ & 022 \\
\hline 17 & Forum for Environment & 03/05/2017 & 020 \\
\hline 18 & Micro Enterprise Bureau of Addis Ababa City & $27 / 03 / 2017$ & 019 \\
\hline 19 & Trade and Industry Bureau of Addis Ababa City & $10 / 05 / 2017$ & 018 \\
\hline 20 & Land Management Bureau of Addis Ababa City & $26 / 04 / 2017$ & $\begin{array}{l}0 \\
3\end{array}$ \\
\hline 21 & Construction and Design Licensing Bureau of Addis Ababa City & $04 / 05 / 2017$ & 011 \\
\hline 22 & Community Participation and Consultation Agency of Addis Ababa City & $28 / 04 / 2017$ & 026 \\
\hline 23 & Water Aid Ethiopia & $14 / 05 / 2017$ & 013 \\
\hline 24 & Horn of Africa Regional Environmental Center \& Network & $28 / 04 / 2017$ & 24 \\
\hline 25 & Land Information Center of Addis Ababa City & $28 / 04 / 2017$ & 23 \\
\hline 26 & Youth Association of Addis Ababa City & $27 / 04 / 2017$ & 25 \\
\hline 27 & Bole Sub City of Addis Ababa City & $17 / 07 / 2017$ & 27 \\
\hline 28 & Addis Ketema Sub City of Addis Ababa City & $17 / 07 / 2017$ & 28 \\
\hline 39 & Solid Waste Disposal and Cleaning Agency of Addis Ababa City & $18 / 07 / 2017$ & 29 \\
\hline 30 & House development Bureau of Addis Ababa City & 03/05/2017 & 010 \\
\hline
\end{tabular}

Table 3 The date of focus group discussion forums Source Addis Ababa Environmental Protection Authority (2017)

\begin{tabular}{llll}
\hline No & Focus group discussion & $\begin{array}{l}\text { Date of Focus group } \\
\text { discussions }\end{array}$ & Remarks \\
\hline 1 & Focus group discussion 1 & From 16/07/2017 & 6 focus group discussion participants \\
2 & Focus group discussion 2 & From 19/07/2017 & 7 focus group discussion participants \\
3 & Focus group discussion 3 & From 20/07/2017 & 5 focus group discussion participants \\
\hline
\end{tabular}


volume of wastes that are dumped by the industries, households, hospitals, academic institutions, private business organizations, and others.

Open Access This article is distributed under the terms of the Creative Commons Attribution 4.0 International License (http://creativeco mmons.org/licenses/by/4.0/), which permits unrestricted use, distribution, and reproduction in any medium, provided you give appropriate credit to the original author(s) and the source, provide a link to the Creative Commons license, and indicate if changes were made.

\section{References}

Abraham K (2012) Challenges and opportunities of riverbank urban agriculture: the case of Mekanisa, Gofa and saris vegetable producer cooperative, MA thesis, Addis Ababa University

Addis Ababa Environmental Protection Authority (2017) Quarterly report on river protection and conservation activities

Addis Ababa Rivers Riversides Climate Change Adaptation Project Office (2017a) Addis Ababa Rivers and Riversides Management Board discussion report

Addis Ababa Rivers Riversides Climate Change Adaptation Project Office (2017b) 100 K.M. 100 meter river cleaning rally project discussion paper

Addis Ababa Rivers Riversides Climate Change Adaptation Project Office (2017c) Annual performance evaluation report

Agajie M (2007) Suitability assessment of the Little Akaki River for irrigation, Master's thesis, Addis Ababa university. Retrieved from http://etd.aau.edu.et/bitstream/123456789/3935/2/Agaje\%20Mek onnen.pdf

Almeida V, Getschko D, Afonso C (2015) The origin and evolution of multistakeholder models. IEEE Internet Comput 19:74-79. https ://doi.org/10.1109/MIC.2015.15

Ansell C, Gash A (2007) Collaborative Governance in Theory and Practice. J Public Adm Res Theory 18(4):543-571. https://doi. org/10.1093/jopart032

Berisso T, Zeleke T, Lamessa D, Taddesse B (2016) Socio-economic assessment of rivers and river side's development in Addis Ababa (Research, Addis Ababa University)

Bhattcherjee A (2012) Social science research: principles, methods, and practices. In: Textbooks collection. Book 3. http://scholarcom mons.usf.edu/oa_textbooks/3

Bryson M, Crosby B, Stone M (2015) Designing and implementing Cross-sector collaborations: needed and changing. Public Adm Rev. https://doi.org/10.1111/puar.12432

Cameron H (2017) The political ontology of collaborative water governance. Water Int 42(3):254-270. https://doi.org/10.1080/02508 060.2017.1309507

Chali D (2015) Odel based water supply network assessment: case of gefersa supply system. Master thesis, Addis Ababa University. Retrieved from http://etd.aau.edu.et/bitstream/123456789/4308/3/ Chali\%20Dereje.pdf

Chan N (2009) Issues and challenges in water governance in Malaysia. Iran J Environ Health Sci Eng 6(3):143-152

Emerson K, Nabatchi T, Balogh S (2011) An integrative framework for collaborative governance. J Public Adm Res Theory 54(4):768781. https://doi.org/10.1093/jopart/mur011

Ethiopian Environmental Protection Authority (2007) Preliminary survey of pollution load on Akaki River, Little Akaki and Kebenariver. Unpublished Report, Addis Ababa, Ethiopia
Franzen F, Hammer M, Balfors B (2014) Institutional development for stakeholder participation in local water management: an analysis of two Swedish catchments. Land Use Policy 43:217-227. https ://doi.org/10.1016/j.landusepol.2014.11.013

Guillermo C, André B (2017) Is a corrupt government totally unacceptable? West Eur Politics 40(4):645-662. https://doi. org/10.1080/01402382.2017.1280746

Holt A, Moug P, Lerner D (2012) The network governance of urban river corridors. Ecol Soc 17(4):25. https://doi.org/10.5751/ ES-05200-170425

Kothari C (2004) Research methodology: methods and techniques. New age international private limited, publishers. ISBN (13): 978-81-224-2488-1

Leta S, Lema E, Alemu T, Abate Z, HaileMariamm H, Mekonnen A, Sahle M, Teshome G, Regassa C, Abate S (2016) Addis Ababa City Rivers pollution and sanitation studies project. Unpublished Report, Addis Ababa, Ethiopia

Meklit D, Mehammed A, Nuri M, Jemal A, Teshome N, Meseret M (2016) River assessment on Akaki River pollution and solid and liquid waste (Report to Addis Ababa Environmental Protection Authority)

Morse R, Stephens J (2012) Teaching collaborative governance: phases, competencies, and case-based learning. J Public Aff Educ 18(3):565-583

Newig J, Fristch O (2009) Environmental governance: Participatory, multi-level and effective? J Environ Policy Gov 19:197-214. https ://doi.org/10.1002/eet.509

Olsson L, Head B (2015) Urban water governance in times of multiple stressors: an editorial. Ecol Soc 20(1):27. https://doi.org/10.5751/ ES-07300-200127

Rosemery O (2014) Collaborative governance in New Zealand: important choices ahead. Newealand, Fulbright New Zealand. Retrieved from https://www.fulbright.org.nz/wp/

Salman M, Daniel B (2006) Regulatory frameworks for water resources management: a comparative study

Solomon A, Seyoum M, Seyoum L (2011) Assessing human impacts on the greater Akaki River, Ethiopia using macroinvertebrates. J Sci 34(2):89-98

Sophia J, Mark T (2006) Why rehabilitate urban river systems? J R Geogr Soc 38. Retrieved from http://isites.harvard.edu/fs/docs/icb. topic598628.files/urban\%20river_Findlay.pdf/. ISSN 0004-0894

Sutcliffe J (2012) Multi-level governance in a Canadian setting: the reform of the Detroit River border crossing. Reg Fed Stud 22(2): $141-158$

Tamiru A (2003) Scientific report on the groundwater vulnerability mapping of the Addis Ababa water supply aquifers. Retrieved from http://s3.amazonaws.com/zanran_storage/www.unep.org/ ContentPages/7893848pdf

Vodden K (2015) Governing sustainable coastal development: the promise and challenge of collaborative governance in Canadian coastal watersheds. Can Geogr 59:167-180. https://doi. org/10.1111/cag. 12135

Warner F (2006) More sustainable participation? Multi-stakeholder platforms for integrated catchment management. Water Resour Dev 22(1):15-35

Yin R (2009) Case study research: design and methods, applied social research methods series, vol 5, 4th edn. Sage Public, Thousand Oaks

Publisher's Note Springer Nature remains neutral with regard to jurisdictional claims in published maps and institutional affiliations. 